\title{
Biogenic hydroxysulfate green rust, a potential electron acceptor for SRB activity
}

Running title: Microbial reduction of $\mathrm{GR}\left(\mathrm{SO}_{4}{ }^{2-}\right)$.

Asfaw Zegeye, Lucie Huguet, Mustapha Abdelmoula," Cédric Carteret, Martine Mullet, and Frédéric Jorand

${ }^{1}$ Laboratoire de Chimie Physique et Microbiologie pour l'Environnement (LCPME), UMR 7564 CNRS-Université Henri Poincaré-Nancy 1, 405, rue de Vandœuvre, F-54600 Villerslès-Nancy, France.

Corresponding author

E-mail: abdelmoula@1cpme.cnrs-nancy.fr

Revised version

Submitted : 06/25/07 


\begin{abstract}
Microbiological reduction of a biogenic sulfated green rust $\left(\mathrm{GR} 2\left(\mathrm{SO}_{4}{ }^{2-}\right)\right.$ ), was examined using a sulfate reducing bacterium (Desulfovibrio alaskensis). Experiments investigated whether $\mathrm{GR} 2\left(\mathrm{SO}_{4}{ }^{2-}\right)$ could serve as a sulfate source for D. alaskensis anaerobic respiration by analyzing mineral transformation. Batch experiments were conducted using lactate as the electron donor and biogenic $\mathrm{GR} 2\left(\mathrm{SO}_{4}{ }^{2-}\right)$ as the electron acceptor, at circumneutral $\mathrm{pH}$ in unbuffered medium. $\mathrm{GR} 2\left(\mathrm{SO}_{4}{ }^{2-}\right)$ transformation was monitored with time by X-ray diffraction (XRD), Transmission Mössbauer Spectroscopy (TMS), Diffuse Reflectance Infrared Fourier Transform Spectroscopy (DRIFTS), Transmission Electron Microscopy (TEM) and X-ray Photoelectron Spectroscopy (XPS). The reduction of sulfate anions and the formation of iron sulfur mineral were clearly identified by XPS analyses. TMS showed the formation of additional mineral as green rust (GR) and vivianite. XRD analyses discriminated the type of the newly formed GR as GR1. The formed GR1 was GR1 $\left(\mathrm{CO}_{3}{ }^{2-}\right)$ as indicated by DRIFTS analysis. Thus, the results presented in this study indicate that $D$. alaskensis cells were able to use $\mathrm{GR} 2\left(\mathrm{SO}_{4}{ }^{2-}\right)$ as an electron acceptor. $\mathrm{GR} 1\left(\mathrm{CO}_{3}{ }^{2-}\right)$, vivianite and an iron sulfur compound were formed as a result of $\mathrm{GR} 2\left(\mathrm{SO}_{4}{ }^{2-}\right)$ reduction by $D$. alaskensis. Hence, in environments where geochemical conditions promote biogenic $\mathrm{GR} 2\left(\mathrm{SO}_{4}{ }^{2-}\right)$ formation, this mineral could stimulate the anaerobic respiration of sulfate reducing bacteria.
\end{abstract}




\section{INTRODUCTION}

Green rusts (GRs) are Fe(II-III) layered double hydroxysalts hydroxides belonging to the sjögrenite-pyroraurite mineral class (Génin et al., 1998; Hansen, 1989). The crystallographic structure consists of positively charged trioctahedral metal sheets alternating with negatively charged hydrated interlayers of anions. X-ray diffraction analysis distinguishes two different types of GR, namely GR1 and GR2 (Bernal et al., 1959). GR1 contains planar or spherical anions (e.g., $\mathrm{CO}_{3}{ }^{2-}, \mathrm{Cl}^{-}$) (Abdelmoula et al., 1996; Refait et al., 1998), whereas GR2 contains non-planar anions (e.g., $\mathrm{SeO}_{4}{ }^{2-}, \mathrm{SO}_{4}{ }^{2-}$ ) (Hansen et al., 1994; Refait et al., 2000; Simon et al., 2003). Direct evidence for the presence of green rusts in hydromorphic soils (Abdelmoula et al., 1998; Feder et al., 2005; Trolard et al., 1997) and their occurrence during corrosion of iron in drinking water pipes (Stampfl, 1969) or in seawater (Génin et al., 1993; Olowe et al., 1989; Refait et al., 2003a) have been widely reported.

Fe(II-III) minerals such as green rust and magnetite, that could be formed through bacterial Fe(III) reduction (Fredrickson et al., 1998; Glasauer et al., 2003; Ona-Nguema et al., 2002; Zachara et al., 2002), are commonly generated as a result of interaction between microrganisms and their surrounding environment (Konhauser, 1997). These biogenic Fe(IIIII) minerals are relevant because they could support bioreduction processes by serving as electron acceptors. Therefore, an understanding of the chemical and biological factors controlling the reduction of these minerals appears to be essential for predicting the impact of microbial anaerobic respiration (Fredrickson et al., 1998). For instance, S. putrefaciens strain CN32 and MR-1 can use Fe(III) in crystalline biogenic magnetite as electron acceptors (Dong et al., 2000). To the best of the author's knowledge, the availability of other Fe(II-III) minerals, such as green rust (GRs), to assist the respiration of anaerobic bacteria has not yet been investigated. 
The GR2 $\left(\mathrm{SO}_{4}{ }^{2-}\right)$ and sulfate reducing bacteria (SRB) are found to be associated with corrosion products in seawater (Olowe et al., 1990). SRB are the most extensively studied microorganisms in relation to biocorrosion and are considered as the main causative organisms in microbiologically influenced corrosion (MIC) in seawater (Beech and Gaylarde, 1999; Geesey et al., 2000; Hamilton and Lee, 1995). These bacteria use organic sources or $\mathrm{H}_{2}$ as electron donors and sulfate as the final electron acceptor during their anaerobic respiration (Hamilton, 1998; Marchal, 1999). Lee et al., (2005) showed the co-existence of SRB and dissimilatory iron reducing bacteria (DIRB) on carbon steel submerged in ocean water. The formation of GR2 $\left(\mathrm{SO}_{4}{ }^{2-}\right)$ has been shown to occur during bio-reduction of lepidocrocite in $S$. putrefaciens culture (Ona-Nguema et al., 2004; Zegeye et al., 2005). Therefore, the sulfate in the mineral could serve as an electron acceptor for SRB anaerobic respiration. Thus, DIRB could supply the electron acceptor for SRB from the product of their own anaerobic Fe(III) respiration allowing the SRB activities.

In a previous study Zegeye et al., (2005), have focused on the formation and the characterization of a biogenic GR2 $\left(\mathrm{SO}_{4}{ }^{2-}\right)$. The present study was initiated to examine the potential for biotically formed $\mathrm{GR} 2\left(\mathrm{SO}_{4}{ }^{2-}\right)$ to serve as a sulfate source for the anaerobic respiration of SRB. Because the initial green rust mineral was formed by a dissimilatory iron reducing bacterium, we examine what can be considered as a biotically coupled process.

The solid phase was inoculated with strictly anaerobic sulfate reducing bacteria (Desulfovibrio alaskensis), recovered from a soured oil well, using lactate as the electron donor in unbuffered medium. We specifically focus on the characterization of mineral phase transitions during the microbial reduction of sulfate from the biotic GR2 $\left(\mathrm{SO}_{4}{ }^{2-}\right)$. We used $\mathrm{X}$ ray Diffraction (XRD), Transmission Mössbauer Spectroscopy (TMS), Diffuse Reflectance Infrared Fourier Transform Spectroscopy (DRIFTS), Transmission Electron Microscopy 
(TEM) and X-ray Photoelectron spectroscopy (XPS) to investigate the solid phase transformation resulting from $D$. alaskensis activity. 


\section{MATERIALS AND METHODS}

\subsection{GR2 $\left(\mathrm{SO}_{4}{ }^{2-}\right)$ mineral}

The GR2 $\left(\mathrm{SO}_{4}{ }^{2-}\right)$ was obtained by bacterial dissimilatory Fe reduction as described in Zegeye et al., (2005). Briefly, the GR resulted from the reduction of lepidocrocite $(\gamma-\mathrm{FeOOH})$ by Shewanella putrefaciens CIP 8040 using $\mathrm{H}_{2}$ as electron donor. According to XRD, DRIFTS and TMS analyses, about $55 \%$ of $\gamma$-FeOOH was transformed into a single iron(IIIII)-bearing mineral i.e $\mathrm{GR} 2\left(\mathrm{SO}_{4}{ }^{2-}\right)$.

After 3 months of incubation, the mixture of $45 \% \gamma$-FeOOH and $55 \%$ GR2(SO ${ }_{4}^{2-}$ ) was recovered by centrifugation and subsequently washed three times with sterilized and oxygenfree $18 \mathrm{M} \Omega \mathrm{cm}^{-1}$ resistivity nano-pure water. This procedure ensures the removal of adsorbed sulfate from the GR2(SO ${ }_{4}^{2-}$ ) (Zegeye et al., 2005). One should note that the mineral mixture was not autoclaved, to avoid any transformation of $\mathrm{GR} 2\left(\mathrm{SO}_{4}{ }^{2-}\right)$ by heating. However, a layer consisting of $S$. putrefaciens cells that was formed on top of the biogenic mixture pellet was carefully removed with a sterile spatula after each washing step and no $S$. putrefaciens cell in the pellet was detected by plate counts method on trypticase soy agar (TSA). The minerals were then dried for 24 hours in an anaerobic chamber $\left(\mathrm{N}_{2}: \mathrm{H}_{2}, 95: 5\right)$ under a $90 \%$ relative humidity. XRD analysis indicated that the $\mathrm{GR} 2\left(\mathrm{SO}_{4}{ }^{2-}\right)$ was not transformed during the washing and drying processes (data not shown). The GR2 $\left(\mathrm{SO}_{4}{ }^{2-}\right)$ in the dried mixture was used as the sole sulfate reservoir and electron acceptor for $D$. alaskensis. 


\subsection{Bacteria and media}

The Desulfovibrio alaskensis strain, initially isolated from a soured oil reservoir in Prudhoe Bay, Alaska, was provided by Pr. Iwona Beech (Portsmouth University). The cells were cultivated to stationary growth phase at $30{ }^{\circ} \mathrm{C}$ in trypticase soy broth (TSB) supplemented with 5 g. $\mathrm{L}^{-1} \mathrm{MgSO}_{4}$ in an anaerobic $\left(\mathrm{N}_{2}: \mathrm{H}_{2}, 95: 5\right)$ chamber (Coy laboratory product). Cells were harvested by centrifugation, washed twice and concentrated in $35 \mathrm{~mL}$ of a sterile $\mathrm{O}_{2}$ free $\mathrm{NaCl} 0.7 \%$ solution. This bacterial suspension was used to inoculate batches containing the mixture of lepidocrocite and GR2 $\left(\mathrm{SO}_{4}{ }^{2-}\right)$.

\subsection{Bioreduction assays}

The batch medium (sodium lactate, $3.5 \mathrm{~g} \mathrm{~L}^{-1}$; $\mathrm{MgCl}_{2} \bullet 6 \mathrm{H}_{2} \mathrm{O}, 3.4 \mathrm{~g} \mathrm{~L}^{-1}$; $\mathrm{NaCl}, 0.3 \mathrm{~g} \mathrm{~L}^{-1}$; $\mathrm{K}_{2} \mathrm{HPO}_{4}, 0.5 \mathrm{~g} \mathrm{~L}^{-1} ; \mathrm{CaCl}_{2}, 0.1 \mathrm{~g} \mathrm{~L}^{-1}$ ) was sterilized by autoclaving and purged with filter sterilized $\mathrm{N}_{2} .80 \mathrm{~mL}$ of the medium was dispensed into sterile $100 \mathrm{~mL}$ flasks and crimp sealed with butyl rubber stoppers. Samples of $0.402 \pm 0.002 \mathrm{~g}$ of biologically produced $\mathrm{GR} 2\left(\mathrm{SO}_{4}{ }^{2-}\right)$ (containing $\gamma$-FeOOH) were introduced into the flasks in the anaerobic chamber. D. alaskensis cell suspensions were added to produce a final concentration of $4.4 \times 10^{8}$ colony forming unit (CFU) $\mathrm{CFU} \mathrm{mL} \mathrm{mL}^{-1}$. A pH of 7.5 was measured after all components were mixed. Cultures were incubated at $30{ }^{\circ} \mathrm{C}$ in darkness and each treatment was replicated four times. A first control sample was prepared with $0.07 \mathrm{~g}$ of lepidocrocite with D. alaskensis cells, in order to control if $D$. alaskensis was able to reduce Fe(III) without sulfate under the experimental conditions. A second control sample was cell free and otherwise identical to the biotic samples. These controls were checked for mineral stability, after 25 days of incubation in the reduction 
media, by XRD analysis (data not shown). A third control was carried out with an abiotically formed GR2 $\left(\mathrm{SO}_{4}{ }^{2-}\right)$ otherwise identical to the biotic sample in order to determine if the presence of $\gamma$-FeOOH affect the mineralogical bio-transformation of the GR2( $\left.\mathrm{SO}_{4}{ }^{2-}\right)$. This control served also to check if a residual activity of $S$. putrefaciens cells in the biotic assays could modify the transformation of GR2 $\left(\mathrm{SO}_{4}{ }^{2-}\right)$ by D. alaskensis. This control was analyzed for mineral transformation after 3 and 20 days of incubation by XRD and DRIFTS.

\subsection{Chemical Analysis}

At selected time points, $1 \mathrm{~mL}$ of suspension was removed from the reduction medium, in the anaerobic chamber, introduced directly into $1 \mathrm{~mL} \mathrm{HCl}(2 \mathrm{~N})$ and incubated for one week. This $1 \mathrm{~N} \mathrm{HCl}$ extraction ensures the dissolution of the biogenic $\mathrm{Fe}(\mathrm{II}) . \mathrm{Fe}^{2+}$ concentration was then determined by the modified 1,10-phenanthroline method (Fadrus and Maly, 1975).

\subsection{Instrumentation}

\subsubsection{X-ray diffraction}

After sampling, the suspension was filtered through $0.45 \mu \mathrm{m}$ pore membrane filters under $\mathrm{N}_{2}: \mathrm{H}_{2}(95: 5)$ atmosphere. The obtained wet paste was spread out on a glass plate and coated with glycerol to inhibit oxidation (Hansen, 1989). The XRD data were collected with a D8 Bruker diffractometer, equipped with a monochromator and a position-sensitive detector. The X-ray source was a Co anode $(\lambda=0.17902 \mathrm{~nm})$. The diffractogram was recorded in the 3 $-642 \theta$ range, with a $0.0359^{\circ}$ step size and a collecting time of 3 seconds per point. 


\subsubsection{Transmission Electron Microscopy}

Transmission electron microscopy was conducted using a CM20/STEM Philips with a voltage of $200 \mathrm{kV}$. One drop of the suspension was laid on an amorphous carbon-coated grid and loaded into the analysis holder of the microscope under $10^{-8}$ Torr vacuum.

\subsubsection{Transmission Mössbauer Spectroscopy}

Mössbauer spectra were obtained from a constant acceleration Mössbauer spectrometer connected to a 512 multichannel analyzer. The amplifier output and the drive mechanism were manufactured by Halder Electronics $\mathrm{GmbH}$. The detector consisted of an $\mathrm{NaI}(\mathrm{Tl})$ scintillation counter. The source of $50 \mathrm{mCi}{ }^{57} \mathrm{Co}$ in $\mathrm{Rh}$ matrix was maintained at room temperature. The spectrometer was calibrated with a $25-\mu \mathrm{m}$ foil of alpha-Fe at room temperature and isomer shifts were given relative to this reference. Aliquots were taken from the well-homogenized medium and the iron bearing particles were concentrated by filtration (0.45 $\mu \mathrm{m}$ pore size) under $\left(\mathrm{N}_{2}: \mathrm{H}_{2}, 95: 5\right)$ atmosphere inside an anaerobic chamber. The sample absorbers were immediately cooled to the liquid nitrogen temperature and maintained until measurements were taken. To prevent oxidation, they were quickly transferred to the cryostat under an inert He atmosphere before measurements. The maximum area density of Fe in the samples was approximately $10 \mathrm{mg} \mathrm{cm}^{-2}$ and thickness effects were assumed to be negligible. The spectra were fitted with the Recoil Software of Lagarec and Rancourt (http://www.physics.uottawa.ca/ recoil) (Lagarec and Rancourt, 1997), using the Lorentzian or pseudo-Voigt method. The parameters resulting from any computer fitting must be 
mathematically and physically significant (chi ${ }^{2}$ minimization); in particular the width of all lines must be small enough.

\subsubsection{Diffuse Reflectance Infrared Fourier Transform Spectroscopy}

A Fourier transform infrared spectrometer (Perkin-Elmer 2000), equipped with a $\mathrm{KBr}$ beam splitter and a DTGS detector, was used for sample characterization by vibrational spectroscopy. The spectral resolution and the total acquisition time were $4 \mathrm{~cm}^{-1}$ and $10 \mathrm{~min}$, respectively. FTIR spectra in diffuse reflectance mode were collected using Harrick DRA-2CI equipment. To perform the analysis, the washed and dried samples were first diluted in a $\mathrm{KBr}$ matrix (5 wt.\%). The samples were then mixed gently with $\mathrm{KBr}$ in an agate mortar, so that the mixtures were not subjected to elevated pressures. The samples were prepared in an anaerobic chamber $\left(\mathrm{N}_{2}: \mathrm{H}_{2}, 95: 5\right)$ to avoid exposure to oxygen and enclosed in an airtight Harrick HVCDRP cell with KRS-5 windows for infrared analysis. The reflectances $R_{s}$ of the sample and $R_{r}$ of pure $\mathrm{KBr}$, used as a non-absorbing reference powder, were measured under the same conditions. Iron oxide-hydroxide reflectance is defined as $R=R_{s} / R_{r}$. The spectra are shown in pseudo-absorbance $(-\log R)$ mode.

\subsubsection{X-Ray Photoelectron Spectroscopy}

X-ray photoelectron spectra were recorded with a KRATOS Axis Ultra instrument using monochromatic Al Ka X-rays $(\mathrm{h} v=1486.6 \mathrm{eV})$ operated at $150 \mathrm{~W}$. The samples were pressed onto a $\mathrm{Cu}$ tape on a holder and introduced into the spectrometer. The base pressure of the analytical chamber was approximately $10^{-9}$ Torr. The spectra were collected at normal $\left(90^{\circ}\right)$ take-off angle. Survey scans were used to determine the chemical elements at the sample 
surface. They were acquired with a pass energy of $160 \mathrm{eV}$ and a X-ray spot size of $0.3 \times 0.7$ $\mathrm{mm}$. Narrow region electron spectra were used to determine the chemical state information. They were acquired with an analyser pass energy of $20 \mathrm{eV}$ and an X-ray spot size of $0.3 \times 0.7$ $\mathrm{mm}$. The spectral resolution is $0.5 \mathrm{eV}$. The binding energy was calibrated by assigning the C(1s) peak to $284.6 \mathrm{eV}$. Spectra for sulfur were fitted using a Shirley Background (Shirley, 1972) and a pseudo-voigt peak model. 


\section{Results}

\subsection{Monitoring of biomass, $\mathrm{pH}$ and $\mathrm{Fe}(\mathrm{II})$}

Concerning the biomass, the cell cultivability has been followed over time. No growth is observed in bioreductions assays, the total cultivable cells remaining stable from $4.410^{8}$ CFU.mL ${ }^{-1}$ to $210^{8}$ CFU.mL ${ }^{-1}$ during the incubation time. Cultivable cells fall down to 1.0 $10^{5}$ CFU.mL ${ }^{-1}$ in the control containing lepidocrocite and SRB without the single potential electron acceptor, the GR2 $\left(\mathrm{SO}_{4}{ }^{2-}\right)$, indicating that GR is needed to maintain biomass in a steady-state.

Visual changes inside the batch bottles were evident within 3 days. The color of the solid phase changed from blue-green to black, suggesting a mineral transformation. Moreover, the characteristic $\mathrm{H}_{2} \mathrm{~S}$ odor, escaping from the bottles when aliquots were removed for analyses, signaled the reduction of sulfate anions. Fe(II) concentration in the treatments immediately increases after the inoculation of SRB and during the time of incubation (Fig. 1). The $\mathrm{pH}$ remains constant and equal to 7.5 during the experiment. Approximate values of 25 $\mathrm{mM}$ were reached, indicating $\mathrm{Fe}(\mathrm{III})$ reduction of either $\gamma$-FeOOH or $\mathrm{GR} 2\left(\mathrm{SO}_{4}{ }^{2-}\right)$. In the cell free control assay with $\mathrm{GR} 2\left(\mathrm{SO}_{4}{ }^{2-}\right), \mathrm{Fe}(\mathrm{II})$ concentrations reached around $8 \mathrm{mM}$, during the same time of incubation. This suggests a residual activity of $S$. putrefaciens cells since the mixture $\mathrm{GR} 2\left(\mathrm{SO}_{4}{ }^{2-}\right)$ and $\gamma-\mathrm{FeOOH}$ was not sterilized. However, the concentration of $\mathrm{Fe}(\mathrm{II})$ in the assay are about 3 times higher than those in the blank experiment, thus indicating an extensive reduction by $D$. alaskensis activity. Higher $\mathrm{Fe}(\mathrm{II})$ concentrations than the cell free control were never found in the assay containing only $\gamma$-FeOOH with SRB. Thus, the 
enhanced reduction of $\mathrm{Fe}(\mathrm{III})$ in the presence of the bio-generated $\mathrm{GR} 2\left(\mathrm{SO}_{4}{ }^{2-}\right)$ plus $\gamma$-FeOOH is not due to the biotic reduction of $\gamma-\mathrm{FeOOH}$ by $D$. alaskensis.

Taking these different results into consideration, the increase in Fe(II) concentration in the treatments containing SRB cells and the mixture of the bio-generated GR2 $\left(\mathrm{SO}_{4}{ }^{2-}\right)$ plus $\gamma$ FeOOH indicates the abiotic reduction of $\gamma$-FeOOH and/or $\mathrm{GR} 2\left(\mathrm{SO}_{4}{ }^{2-}\right)$ by $\mathrm{H}_{2} \mathrm{~S}$, which is the reaction product of bacterial sulfate reduction.

\subsection{Mineral products of biogenic GR2( $\left.\mathrm{SO}_{4}{ }^{2-}\right)$ reduction by $D$. alaskensis: evidence of sulfate reduction}

\subsubsection{X-ray diffraction}

Prior to SRB inoculation, the diffraction patterns exhibit only the diffraction lines of the biogenerated GR2 $\left(\mathrm{SO}_{4}{ }^{2-}\right)$ and $\gamma$-FeOOH (Fig. 2A) in agreement with previous data (Hansen et al., 1994; Ona-Nguema et al., 2004; Simon et al., 1997; Zegeye et al., 2005). Experimental GR2 $d$-spacings are similar to those previously obtained in biotic and abiotic conditions for $\mathrm{GR} 2\left(\mathrm{SO}_{4}{ }^{2-}\right)$. After 3 days of incubation with $D$. alaskensis, the XRD pattern exhibits diffraction lines of $\mathrm{GR} 2\left(\mathrm{SO}_{4}{ }^{2-}\right)$ and $\gamma-\mathrm{FeOOH}$, the intensity of which are both strongly decreased. An additional reflection line with $d$-spacing characteristic of vivianite $\left[\left(\mathrm{Fe}_{3}\left(\mathrm{PO}_{4}\right)_{2} \bullet 8 \mathrm{H}_{2} \mathrm{O}\right]\left(0.684 \mathrm{~nm}, 14.9^{\circ} 2 \theta\right)\right.$ is also observed. Significant mineralogical changes are revealed by the XRD pattern after 20 days of incubation. X-ray diffraction peaks of GR2 and $\gamma$-FeOOH disappear and new lines ascribable to the GR1 are observed, which was the predominant product after 20 days of incubation. This GR1 is a $\mathrm{GR} 1\left(\mathrm{CO}_{3}{ }^{2-}\right)$ as established by DRIFTS analysis (Drissi et al., 1995; Ona-Nguema et al., 2002). The peak at $0.684 \mathrm{~nm}\left(14.9^{\circ}\right.$ $2 \theta$ ) assigned to vivianite is also present. The X-ray diffraction patterns of assay containing the 
biotic GR2 $\left(\mathrm{SO}_{4}{ }^{2-}\right)$ plus $\gamma$-FeOOH do not show further changes after 300 days of incubation and are consistent with the presence of a mixture of $\mathrm{GR} 1\left(\mathrm{CO}_{3}{ }^{2-}\right)$ and vivianite.

The same mineralogical transformation is observed in the control run with the chemically synthesized GR2 $\left(\mathrm{SO}_{4}{ }^{2-}\right.$ ) (Fig. 2B). Indeed, characteristic peaks of vivianite and GR1 are revealed after 3 and 25 days of incubation respectively. This control indicates that the presence of $\gamma$-FeOOH does not affect the biotransformation of the biogenic GR2 $\left(\mathrm{SO}_{4}{ }^{2-}\right)$. It also shows that biotransformation of the GR2 $\left(\mathrm{SO}_{4}{ }^{2-}\right)$ was not due to a residual activity of $S$. putrefaciens cells but to $D$. alaskensis cells. The cell-free control does not show any $\mathrm{GR} 2\left(\mathrm{SO}_{4}{ }^{2-}\right)$ transformation. This observation further supports the idea that the observed mineral transformation is attributable to the activity of D. alaskensis cells.

\subsubsection{Mössbauer Spectroscopy}

Mössbauer measurements (between 215 and $13 \mathrm{~K}$ ) were performed to follow the mineralogical transformation during the incubation period (Fig. 3). In contrast to XRD, this method provides information on compounds that do not exhibit long-range structural order (poorly crystalline solids). The starting mineral exhibits doublets $D_{1}$ and $D_{2}$ corresponding to GR and the doublet $D_{\mathrm{L}}$ is assigned to paramagnetic $\mathrm{Fe}^{3+}$ in lepidocrocite at $77 \mathrm{~K}$. The doublet $D_{1}$ corresponds to the ferrous state, whereas the $D_{2}$ is assigned to the ferric state. These characteristic features indicate that these components are associated with ordered arrangements of $\mathrm{Fe}^{2+}$ and $\mathrm{Fe}^{3+}$ in the brucite sheet. As expected, the $\mathrm{Fe}(\mathrm{II}) / \mathrm{Fe}$ (III) ratio in the GR formed is about 2. It was not possible to discriminate between GR1 and GR2 by TMS because this technique is sensitive to the local environment of the probe nucleus, Fe. The hyperfine parameters result from the perturbation of these nuclear levels by their electronic environment. In contrast, XRD is a global method (crystallographic) technique and allow to 
observe the structural specificity of the GRs which can intercalate three dimensional anions (GR2) or planar anions (GR1).

In agreement with XRD the Mössbauer spectrum obtained after 3 days of incubation, displays two new ferrous components assigned to vivianite. These paramagnetic quadrupole doublets correspond to vivianite with two crystal sites for $\mathrm{Fe}(\mathrm{II}) . D_{1}$ is assigned to vivianite-Fe1 and $D_{2}$ to vivianite-Fe2. The TMS analysis shows also a new magnetic component which exhibited sextets, $\mathrm{S}_{\mathrm{A}}$ and $\mathrm{S}_{\mathrm{B}}$. The hyperfine parameters of this spectrum are $\mathrm{S}_{\mathrm{A}}(\delta=0.47 \mathrm{~mm}$ $\left.\mathrm{s}^{-1} ; \mathrm{H}=475 \mathrm{kOe}\right)$ and $\mathrm{S}_{\mathrm{B}}\left(\delta=0.84 \mathrm{~mm} \mathrm{~s}^{-1} ; \mathrm{H}=277 \mathrm{kOe}\right)$. This phase is not identified by XRD analysis, probably due to its poor crystallinity and/or its low amont. In spite of the appearance of a new $\mathrm{Fe}(\mathrm{II})$ component ascribable to vivianite, the total amount of $\mathrm{Fe}(\mathrm{II})$ is smaller than that of $\mathrm{Fe}(\mathrm{III})$, which corresponds to two overlapping doublets (Fe(III) of lepidocrocite and GR respectively). The $215 \mathrm{~K}$ Mössbauer spectral pattern for the bio-reduced material after 20 days of incubation is similar to the pattern for 3 days of incubation, except that the total amount of paramagnetic Fe(III) decreases substantially. The decrease of the lepidocrocite doublets is probably due to its reductive dissolution by $\mathrm{H}_{2} \mathrm{~S}$ that was produced by sulfate reduction. After 300 days of incubation, the paramagnetic components attributable to vivianite and the GR are always present; in addition, the intensity of the magnetically ordered component increased. This component is probably iron sulfide in the form of greigite $\left(\mathrm{Fe}_{3} \mathrm{~S}_{4}\right)$ supported by the values of the hyperfine magnetic fields $H$ of its two sextets (280 and $355 \mathrm{kOe})$. Greigite, $\mathrm{Fe}_{3} \mathrm{~S}_{4}$, is the sulfur analogue of magnetite $\left(\mathrm{Fe}_{3} \mathrm{O}_{4}\right)$ and has a similar inverse spinel structure.

\subsubsection{Characterization of anions in the solid phase}


Figure 4A illustrates the DRIFTS spectral changes occurring after 300 days of incubation of $D$. alaskensis. Spectrum (a) exhibits the typical features of sulfate green rust (Ona-Nguema et al., 2004; Peulon et al., 2003; Zegeye et al., 2005): bands arising from the brucite-like sheets at $515,780,880$ and $1550 \mathrm{~cm}^{-1}$ and bands due to the intercalated sulfate at around $620 / 660$ and $1105 / 1138 \mathrm{~cm}^{-1}$. In addition to these GR spectra lines, this spectrum reveals the presence of $\gamma-\mathrm{FeOOH}$, with a characteristic absorption at $1022 \mathrm{~cm}^{-1}$ (Zegeye et al., 2005). After 300 days of incubation (spectrum b), it is noteworthy that the bands associated with brucite-like sheets are almost unaffected. In contrast, both the characteristic signals of sulfate and the sharp band due to lepidocrocite have disappeared. A large and intense band at $1000 \mathrm{~cm}^{-1}$, with shoulders at 1047, 1101 and $1142 \mathrm{~cm}^{-1}$, assigned to a phosphate solid (Farmer, 1974) appears concomitantly with a very intense peak at $1351 \mathrm{~cm}^{-1}$ with a shoulder at $1395 \mathrm{~cm}^{-1}$ assigned to the carbonate ions intercalated in a GR1 structure (Peulon et al., 2003; Ona-Nguema et al., 2004).

The same result is observed for the control run with the abiotic GR2 $\left(\mathrm{SO}_{4}{ }^{2-}\right)$ (Fig. 4B). The spectrum (a) exhibits the typical features of a sulfate GR as described above. The characteristic signals of sulfate have disappeared after 20 days of incubation (spectrum b). This results indicate that $\gamma-\mathrm{FeOOH}$ doesn't interfere with sulfate reduction in the assay containing the biogenic GR2 $\left(\mathrm{SO}_{4}{ }^{2-}\right)$. This result corroborates the conclusions obtained by XRD, which indicate that the transformation of $\mathrm{GR} 2\left(\mathrm{SO}_{4}{ }^{2-}\right)$ was due to the activity of $D$. alaskensis.

\subsubsection{Surface Analysis by XPS}

Figures 5 and 6 show the high resolution $S(2 p)$ and $F e\left(2 p_{3 / 2}\right)$ spectra for the mixture $\mathrm{GR} 2\left(\mathrm{SO}_{4}{ }^{2-}\right) / \gamma-\mathrm{FeOOH}$ and the products obtained after 300 days of incubation $\left(\mathrm{GR} 1\left(\mathrm{CO}_{3}{ }^{2-}\right.\right.$ 
)/vivianite) respectively. $\mathrm{S}\left(2 \mathrm{p}_{3 / 2}\right)$ and $\mathrm{Fe}\left(2 \mathrm{p}_{3 / 2}\right)$ binding energies for various model compounds are listed in Table 1.

The $S(2 p)$ spectra are fitted using doublets $2 p_{1 / 2}$ and $2 p_{3 / 2}$ separated by a spin-orbit splitting of $1.2 \mathrm{eV}$ (Fig. 5). The $\mathrm{S}\left(2 \mathrm{p}_{1 / 2}\right)$ peak area is constrained to one-half of the area of $\mathrm{S}\left(2 \mathrm{p}_{3 / 2}\right)$ peak. As expected, a good fit of the spectrum of the GR2 $\left(\mathrm{SO}_{4}{ }^{2-}\right) / \gamma-\mathrm{FeOOH}$ initial mixture is obtained using a doublet with $2 \mathrm{p}_{3 / 2}$ binding energy at $168.2 \mathrm{eV}$ corresponding to sulfate species (Table 2, Fig. 5). No other sulfur species are observed. To adequately fit the $\mathrm{S}(2 \mathrm{p})$ spectrum of the final products, three doublets are required (Table 2 ). The $2 \mathrm{p}_{3 / 2}$ binding energy of the major doublet at $160.9 \mathrm{eV}$ is typically attributed to monosulfide species. Monosulfide species represent $66 \%$ of the whole signal. Additionally, two others doublets are fitted to take into account for the high energy tail of the spectrum. The $2 \mathrm{p}_{3 / 2}$ components are located at 161.8 and $163.3 \mathrm{eV}$ and may correspond to disulfide $\left(S_{2}{ }^{2-}\right)$ and polysulfides $\left(S_{\mathrm{n}}{ }^{2-}\right)$ respectively. The presence of disulfide and polysulfide species was previously reported by Herbert et al. (1998) at the surface of iron monosulfide precipitated in the presence of SRB.

The broad $\mathrm{Fe}\left(2 \mathrm{p}_{3 / 2}\right)$ spectra present a major contribution occurring near $710.5 \mathrm{eV}$ and $710.7 \mathrm{eV}$ for the initial mixture and the final products respectively (Fig. 6). To the best of the authors knowledge, the assignment of Fe(II) and Fe(III) features in XPS spectra of green rusts is not reliably established yet. The reasons for this have to do with the small binding energy difference between the $\mathrm{Fe}\left(2 \mathrm{p}_{3 / 2}\right)$ peaks of $\mathrm{Fe}(\mathrm{II})$ and $\mathrm{Fe}(\mathrm{III})$ coordinated by oxygen, the variety of chemical environments for Fe in GR, and the multiplet structure of Fe XPS spectra. This is probably explained by the small difference in binding energy range between combined to the multiplet structure of iron. Our spectra are made more complex by the presence of several Fe-containing phases. No attempt was therefore made to fit the $\mathrm{Fe}\left(2 \mathrm{p}_{3 / 2}\right)$ spectra. However, the main features observed in Figure 6 are not surprisingly the sum of Fe(II) and $\mathrm{Fe}(\mathrm{III})$ contributions, both corresponding to iron-oxygen bond types in (oxyhydr)oxides 
(Table 1). Note that the $\mathrm{Fe}(\mathrm{II})-\mathrm{O}$ component located at $710 \mathrm{eV}$ is clearly evidenced in the spectrum relative to the initial mixture of $\mathrm{GR} 2\left(\mathrm{SO}_{4}{ }^{2-}\right) / \gamma-\mathrm{FeOOH}$. Of interest is the shoulder that only appears at the low energy side of the $\mathrm{Fe}\left(2 \mathrm{p}_{3 / 2}\right)$ spectrum of the final products. The corresponding binding energy is around $707 \mathrm{eV}$, which typically falls in the range reported for $\mathrm{Fe}(\mathrm{II})-\mathrm{S}$ compounds (Table 1). Note that the binding energy range of $\mathrm{Fe}(\mathrm{II})$ bound to $\mathrm{S}$ is much slower than that of $\mathrm{Fe}(\mathrm{II})-\mathrm{O}$, so that the discrimination between these two components is unambiguous.

XPS data are clearly consistent with the microbial reduction of sulfate. Iron (oxyhydr) oxides are dominantly observed and the formation of an Fe(II)-S compound is suggested.

\subsubsection{Transmission electron microscopy}

TEM images of the inoculated and un-inoculated treatments incubated for 20 days illustrate the presence of numerous crystals. In the control treatment, large hexagonal crystals assigned to GR2 $\left(\mathrm{SO}_{4}{ }^{2-}\right)$ and some vivianite crystals are also observed (data not shown). In the inoculated treatments, two additional mineral phases appear, $\operatorname{GR} 1\left(\mathrm{CO}_{3}{ }^{2-}\right)$ and a highly aggregated mineral structure (Fig. 7A). The elemental analysis of this structure yields prominent $S$ and Fe peaks on EDX spectrum with a $\mathrm{S} / \mathrm{Fe}$ ratio of about 1 (Fig. 7B), thus indicating the probable formation of an Fe-S compound. The SAED pattern of this mineral exhibits a ring-like powder pattern (not shown) consistent with a poor degree of crystallinity. Thus, unequivocal assignment to a particular Fe-S mineral is not possible. 


\section{Discussion}

The experimental results define two major findings. The first one demonstrates that sulfate anions from a biogenic $\mathrm{GR} 2\left(\mathrm{SO}_{4}{ }^{2-}\right)$ serve as sulfate pool for D. alaskensis respiration. The second one reveals that $\mathrm{GR} 1\left(\mathrm{CO}_{3}{ }^{2-}\right)$ and iron sulphur minerals are formed as biogenic products of SRB activity. The formation of vivianite is also observed due to the presence of phosphate in the culture medium.

\subsection{Bio-reduction of $\mathrm{GR2}\left(\mathrm{SO}_{4}{ }^{2-}\right)$}

Under the experimental conditions, the $\mathrm{SO}_{4}{ }^{2-}$ from the $\mathrm{GR} 2\left(\mathrm{SO}_{4}{ }^{2-}\right)$ was accessible for D. alaskensis anaerobic respiration with lactate as the electron source. Indeed, the DRIFTS analysis revealed the disappearance of sulfate bands after 300 days of incubation, suggesting the reduction of sulfate anions by SRB. The XPS analysis corroborates this result as no sulfate signal was observed after the incubation period. The simplified chemical reaction is:

$$
2 \mathrm{CH}_{3} \mathrm{CHOHCOO}^{-}+\mathrm{SO}_{4}{ }^{2-}=2 \mathrm{CH}_{3} \mathrm{COO}^{-}+2 \mathrm{HCO}_{3}^{-}+\mathrm{H}_{2} \mathrm{~S}
$$

The mechanisms by which SRB acquire the sulfate anions trapped in the GR2(SO $\left.{ }_{4}{ }^{2-}\right)$ structure has not been yet established. Laboratory studies have demonstrated that some SRB can reduce sulfate anions bound in minerals by an energy-conserving process (Katrnachuk et al., 2002; Kowalski et al., 2003). These studies highlight the dissolution of the solid phase prior to sulfate reduction. Moreover, the dissolution process could be accelerated by the production of extra-cellular polymeric substances by SRB (Beech and Cheung, 1995; Zinkevich et al., 1996). These findings suggest that dissolution of the mineral occurred prior to sulfate reduction which is in agreement with the biochemical pathway of sulfate reduction 
by SRB. It is preceded by sulfate ion transport into the cells and followed by sulfate activation through ATP sulfurylase (Hamilton, 1998). Thus, it seems likely that the dissolution of $\mathrm{GR} 2\left(\mathrm{SO}_{4}{ }^{2-}\right)$ occurred prior to sulfate anions uptake for D. alaskensis anaerobic respiration. The mechanistic pathway of how SRB utilize the sulfate from the GR2 $\left(\mathrm{SO}_{4}{ }^{2-}\right.$ ) (in situ or $e x$ situ reduction) would require a dedicated and through investigation and is beyond the scope of this work.

Hydrogen sulfide is a product of anaerobic sulfate reduction. The reaction of dissolved $\mathrm{H}_{2} \mathrm{~S}$ with iron oxides has been well documented and was proposed to occur via a reductive dissolution mechanism with strong $\mathrm{pH}$ dependence (Peiffer et al., 1992; Poulton, 2003; Poulton et al., 2002; Yao and Millero, 1996). In the present study carried out at a pH value of around 7, total Fe(II) (solid and soluble phase) concentration increased when the mixture of $\mathrm{GR} 2\left(\mathrm{SO}_{4}{ }^{2-}\right)$ and $\gamma$-FeOOH was incubated with $\mathrm{SRB}$. As $\mathrm{Fe}(\mathrm{II})$ was not detected in the treatment containing only $\gamma-\mathrm{FeOOH}$, it seems that the $\mathrm{Fe}(\mathrm{III})$ reduction observed in these assays was due to an inorganic reduction of $\mathrm{Fe}(\mathrm{III})$ by $\mathrm{H}_{2} \mathrm{~S}$ rather than enzymatic activity of bacterial cells. This hypothesis is corroborated by an earlier study that suggests an enhancement of the alteration of a Fe-rich clay mineral via biogenic sulfide during sulfate reduction (Yi-Lang et al., 2004). Because $\mathrm{H}_{2} \mathrm{~S}$ is reactive towards $\mathrm{Fe}(\mathrm{III})$, hydrogen sulfide may also influence the dissolution of GR2 $\left(\mathrm{SO}_{4}{ }^{2-}\right)$.

\subsection{The by-product of $\mathrm{GR2}\left(\mathrm{SO}_{4}{ }^{2-}\right)$ bioreduction}

TMS and XRD analyses showed the formation of vivianite in the reduction media. In agreement with previous studies vivianite is formed rapidly at circumneutral $\mathrm{pH}$ (Fredrickson et al., 1998; Kukkadapu et al., 2004). The rate of vivianite formation was greater than that of $\mathrm{GR} 1\left(\mathrm{CO}_{3}{ }^{2-}\right)$ under our experimental conditions. Indeed after 3 days of incubation, 
vivianite is the only alteration product in the XRD spectra. This trend was also observed during the bioreduction of ferrihydrite in a phosphate containing media by $S$. putrefaciens CN32 (Kukkadapu et al., 2004). The formation of vivianite in abiotic or biotic systems requires the reaction between ferrous ions and dissolved phosphate anions. The increase in $\mathrm{Fe}(\mathrm{II})$ concentration during the incubation of the mixture of $\mathrm{GR} 2\left(\mathrm{SO}_{4}{ }^{2-}\right)$ plus $\gamma$-FeOOH with SRB supply Fe(II) ions for the precipitation of vivianite. However, the characteristic vivianite line $\left(0.684 \mathrm{~nm}, 14.9^{\circ} 2 \theta\right)$ was also observed after 25 days of incubation in the control experiments (data not shown). The formation of this mineral could be explained by the reaction between aqueous $\mathrm{Fe}^{2+}$ ions which were in equilibrium with the $\mathrm{GR} 2\left(\mathrm{SO}_{4}{ }^{2-}\right)$ (Bourrié et al., 1999) and the dissolved phosphate anions present in the medium. The precipitation of vivianite in solution containing high level of phosphate and in presence of GR2 $\left(\mathrm{SO}_{4}{ }^{2-}\right)$ was also observed in abiotic assay (Hansen and Inge, 1999). Therefore, it was not possible to determine the contribution of bacterial activity to vivianite formation. The $\mathrm{Fe}(\mathrm{II})$ in vivianite probably originates from both $\mathrm{GR} 2\left(\mathrm{SO}_{4}{ }^{2-}\right)$ and $\gamma-\mathrm{FeOOH}$.

Lactate oxidation coupled with sulfate reduction resulted in an increase in carbonate anions (as bicarbonate) within the culture media. DRIFTS and XRD analyses conclusively showed the formation of $\operatorname{GR} 1\left(\mathrm{CO}_{3}{ }^{2-}\right)$ in our experiments. TMS hyperfine parameters indicated that the $\mathrm{Fe}(\mathrm{II}) / \mathrm{Fe}(\mathrm{III})$ ratio of the biogenic $\mathrm{GR} 1\left(\mathrm{CO}_{3}{ }^{2-}\right)$ was around 2 (Drissi et al., 1995, Ona-Nguema et al., 2002). No GR(PO $\left.{ }_{4}{ }^{3-}\right)$ formed in contrast to the study of Parmar et al., (2001) who attribute the precipitation of $\mathrm{GR}\left(\mathrm{PO}_{4}{ }^{3-}\right)$ to phosphate in the reduction media. In contrast, Benali et al., (2001) did not observe the formation of $\mathrm{GR}\left(\mathrm{PO}_{4}{ }^{3-}\right)$ during the incubation of a $\mathrm{GR} 1\left(\mathrm{CO}_{3}{ }^{2-}\right)$ in a phosphate rich media $\left(0.06 \mathrm{M}, \mathrm{Na}_{2} \mathrm{HPO}_{4}\right)$. Accordingly, Kukkadapu et al., (2004) suggested a higher affinity for carbonate rather than for phosphate during GR formation. Moreover Bocher et al., (2004) demonstrated that phosphate anions 
adsorbed preferentially upon the lateral faces of the $\mathrm{GR} 1\left(\mathrm{CO}_{3}{ }^{2-}\right)$ but do not penetrate in the brucite sheet, thus stabilizing the Fe(II-III) mineral.

The formation of $\mathrm{FeS}$ compounds such as greigite $\left(\mathrm{Fe}_{3} \mathrm{~S}_{4}\right)$, mackinawite $\left(\mathrm{FeS}_{1-\mathrm{x}}, 0<\right.$ $\mathrm{x}<0.07)$ or pyrite $\left(\mathrm{FeS}_{2}\right)$ in field settings was often attributed to the presence of sulfatereducing bacteria (Herbert et al., 1998; Neal et al., 2001; Popa and Kinkle, 2000). In agreement with TEM and TMS analyses, XPS analysis also evidenced the formation of a Fe-S compound. The binding energy of the main $S(2 p)$ component (Figure 6) is in agreement with that reported for poorly crystallized compounds such as mackinawite $\mathrm{FeS}_{1-\mathrm{x}} 0<\mathrm{x}<0.07$ and/or greigite $\mathrm{Fe}_{3} \mathrm{~S}_{4}$. Note that mackinawite is the first iron sulfide phase formed by the precipitation of iron (II) and sulfide S(-II) and that greigite is an oxidation product of mackinawite (Boursiquot et al.,2001). The $\mathrm{Fe}(2 \mathrm{p})$ spectra of the final products were consistent with the presence of iron sulfide containing phases, but were equivocal with regards to the specific phase present. Herbert et al. (1998) have previously reported the formation of poorly crystallized precipitates of disordered mackinawite and greigite in media containing SRB. Although none of the analytical techniques used in the present study put forward unequivocal evidence as to the nature of iron sulfide mineral formed, the results obtained by TMS analysis suggested the formation of greigite as the best hypothesis. Indeed, Mössbauer spectra displayed a magnetically ordered compound and the fitting indicated that greigite would be the potential candidate. 


\subsection{Environmental implication}

$\mathrm{GR} 2\left(\mathrm{SO}_{4}{ }^{2-}\right)$ is formed during the marine corrosion of iron in aquatic environments (Olowe et al., 1989; Refait et al., 2003b) and SRB are found in close association with the Fe sulfide phase and GR2 corrosion products (Olowe et al., 1990). Moreover a recent study reported that iron and sulfate reducing bacteria colonized a carbon steel submerged in ocean water, indicating the co-existence of DIRB and SRB (Lee et al., 2005).

In an attempt to integrate the data put forward earlier in this study, we propose a scheme of a corrosion process in which DIRB and SRB are implicated (Fig. 8). Our focus is to illustrate a possible interaction between DIRB and $\mathrm{SRB}$ with $\mathrm{GR} 2\left(\mathrm{SO}_{4}{ }^{2-}\right)$ playing the central role. In such a consortium, the major interaction illustrated between the two bacterial groups could be described as: the secondary mineral formed by the activity of one group, the DIRB, serves as electron acceptor for the second group, the SRB.

In the microenvironment at a corroded surface, we would expect that SRB cells are not in direct contact with the bulk solution but enclosed in a corrosion tubercle. The formation of GR2 $\left(\mathrm{SO}_{4}{ }^{2-}\right)$, through DIRB activity (Fig. 8, path 1) or by an abiotic pathway (Fig. 8, path 2), could allow sulfate to become locally concentrated in the biogenic mineral $\left(2 \mathrm{mM} \mathrm{cm}^{-3}\right)$. This mineral could then serve as an electron acceptor reservoir for SRB that can not reach the bulk solution to use sulfate anions for energy production (Fig. 8, path 3). The reduction of aqueous or embedded sulfate coupled to organic matter oxidation would lead to the formation of $\mathrm{H}_{2} \mathrm{~S}$ and carbonate (Fig. 8, path 4). $\mathrm{H}_{2} \mathrm{~S}$ subsequently reacts with $\mathrm{Fe}(\mathrm{III})$ and/or $\mathrm{Fe}(\mathrm{II})$, which form during corrosion, and contributes to the formation of $\mathrm{Fe}_{\mathrm{x}} \mathrm{S}_{\mathrm{y}}$ compound (Fig. 8, path 5) whereas $\mathrm{CO}_{3}{ }^{2-}$ would react with $\mathrm{Fe}(\mathrm{II})$ and $\mathrm{Fe}(\mathrm{III})$ to precipitate carbonate green rust (Fig. 8, path 6).

In this study, we demonstrated that sulfate anions of a biogenic $\mathrm{GR} 2\left(\mathrm{SO}_{4}{ }^{2-}\right)$ were available for SRB anaerobic respiration. Since the initial green rust was formed by an iron 
reducing bacterium, this study examines what appears to be a biotically coupled process. This lab-based study can contribute to a better understanding of natural systems, which are inherently complex with respect to microorganisms and minerals. In the environment, more than one species would constitute the biofilm on a corroded surface and trophic interactions would not be the only one. Moreover, the environmental chemistry would also be significantly more complex and influence the overall reactions. However, the presence of $\mathrm{Fe}(\mathrm{II}), \mathrm{H}_{2},[\mathrm{CHO}]_{\mathrm{n}}$ and the different solid phases included in the illustration are widely described in the literature to occur during corrosion processes (Beech and Gaylarde, 1999; De Windt et al., 2003; Dubiel et al., 2002; Geesey et al., 2000; Jeffrey and Melchers, 2003). The schema (Figure 8) is merely a discussion of this study and further investigations are needed to validate the model proposed herein. 


\section{ACKNOWLEDGMENTS}

The authors acknowledge I. Bihannic from the Laboratoire Environnement et Minéralogie for the XRD analyses and J. Ghanbaja (Nancy I University) for the TEM analyses. We also thank Pr Herbillon Adrien for encouragement and helpful discussion. We

are, furthermore, indebted to Dr C. Eggleston and the anonymous reviewers for their helpful comments that improved the text 


\section{REFERENCES}

Abdelmoula M., Refait P., Drissi S. H., Mihe J. P., and Génin J.-M. R. (1996) Conversion electron Mössbauer spectroscopy and X-ray diffraction studies of the formation of carbonate-containing green rust one by corrosion of metallic iron in $\mathrm{NaHCO}_{3}$ and $\left(\mathrm{NaHCO}_{3}+\mathrm{NaCl}\right)$ solutions. Corros Sci 38(4), 623-33.

Abdelmoula M., Trolard F., Bourrie G., and Génin J.-M. R. (1998) Evidence for the Fe(II)$\mathrm{Fe}(\mathrm{III})$ green rust "Fougerite" mineral occurrence in a hydromorphic soil and its transformation with depth. Hyperfine Interactions 112(1-4), 235-238.

Arnold R. G., DiChristina T. J., and Hoffmann M. R. (1988) Reductive dissolution of iron(III) oxides by Pseudomonas sp. 200. Biotechnol Bioeng 32(9), 1081-1096.

Beech I. B. and Cheung C. W. S. (1995) Interaction of exopolymers produced by sulphatereducing bacteria with metal ions. Int Biodeter Biodegr. 35, 59-72.

Beech I. B. and Gaylarde C. C. (1999) Recent advances in the study of biocorrosion - an overview. Rev Microbiol. 30, 177-190.

Benali O., Abdelmoula M., Refait P., and Génin J.-M. R. (2001) Effect of orthophosphate on the oxidation products of $\mathrm{Fe}(\mathrm{II})-\mathrm{Fe}(\mathrm{III})$ hydroxycarbonate: the transformation of green rust to ferrihydrite. Geochim Cosmochim Acta 65(11), 1715-26.

Bernal J. O., Dasgupta D. R., and Mackay A. L. (1959) The oxides and hydroxides of iron and their structural inter-relationships. Clay Min Bull 4, 15-30.

Bocher F., Géhin A., Ruby C., Ghanbaja J., Abdelmoula M., and Génin J.-M. R. (2004) Coprecipitation of $\mathrm{Fe}$ (II-III) hydroxycarbonate green rust stabilised by phosphate adsorption. Solid State Sci 6, 117-124.

Bourrié G., Trolard F., Génin J.-M. R., Jaffrezic A., Maitre V., and Abdelmoula M. (1999) Iron control by equilibria between hydroxy-green rusts and solutions in hydromorphic soils. Geochim Cosmochim Acta 63(19-20), 3417-27.

Boursiquot S., Mullet M., Abdelmoula M., Génin J.-M., Ehrahardt J.-J. (2001) The dry oxidation of tetragonal $\mathrm{FeS}_{1-\mathrm{x}}$. Phys Chem Minerals 28, 600-611.

De Windt W., Bonn N., Siciliano S. D., and Verstraete W. (2003) Cell density related $\mathrm{H}_{2}$ consumption in relation to anoxic $\mathrm{Fe}(0)$ corrosion and precipitation of corrosion products by Shewanella putrefaciens. Environ Microbiol 5, 1192-1202.

Dong H., Fredrickson J. K., Kennedy D. W., Zachara J. M., Kukkadapu R. K., and Onstott T. C. (2000) Mineral transformation associated with the microbial reduction of magnetite. Chem Geol 169, 299-318.

Drissi S. H., Refait P., Abdelmoula M., and Génin J.-M. R. (1995) The preparation and thermodynamic properties of iron(II)-iron(III) hydroxide-carbonate (green rust); Pourbaix diagram of iron in carbonate-containing aqueous media. Corros Sci 37, 2025-41.

Dubiel M., Hsu C. H., Chien C. C., Mansfeld F., and Newman D. K. (2002) Microbial iron respiration can protect steel from corrosion. Appl Environ Microbiol 68(3), 1440-5.

Fadrus H. and Maly J. (1975) Suppression of iron(III) interference in the determination of iron(II) in water by the 1,10-phenanthroline method. Analyst 100, 549-54.

Farmer V. C. (1974) The infrared spectra of minerals. Mineralogical society, Monograph 4.

Feder F., Trolard F., Klingelhöfer G., and Bourrié G. (2005) In situ Mössbauer spectroscopy: evidence for green rust (fougerite) in a gleysol and its transformation with time and depth. Geochim Cosmochim Acta 69, 4463-4483. 
Fredrickson J. K., Zachara J. M., Kennedy D. W., Dong H., Onstott T. C., Hinman N. W., and Li S.-m. (1998) Biogenic iron mineralization accompanying the dissimilatory reduction of hydrous ferric oxide by a groundwater bacterium. Geochim Cosmochi. Acta 62(19-20), 3239-3257.

Geesey G. G., Beech I. B., Bremer P. J., Webster B. J., and Weel D. B. (2000) Biocorrosion. In Biofilm II: Process analysis and applications (ed. J. D. Bryers), pp. 281-325. Wiley-Liss.

Géhin A., Ruby C., Abdelmoula M., Benali O., Ghanbaja J., Refait P., and Génin J.-M. R. (2002) Synthesis of Fe(II-III) hydroxysulphate green rust by coprecipitation. Solid State Sci 4(1), 61-66.

Génin J.-M. R., Olowe A. A., Resiak B., Benbouzid-Rollet N. D., Confente M., and Prieur D. (1993) Identification of sulfated green rust 2 compound produced as a result of microbially induced corrosion of steel sheet piles in a harbour. Eur Feder Corros 10, 162-166.

Génin J. M. R., Abdelmoula M., Refait P., and Simon L. (1998) Comparison of the GR(II) lamellar double hydroxide class with the GR(I) pyroraurite class: $\mathrm{Fe}(\mathrm{II})-\mathrm{Fe}(\mathrm{III})$ sulphate and selenate hydroxides. Hyperfine Interact. 3, 313-316.

Glasauer S., Weidler P. G., Langley S., and Beveridge T. J. (2003) Controls on Fe reduction and mineral formation by a subsurface bacterium. Geochim Cosmochim Acta 67(7), $1277-1288$.

Hamilton W. A. (1998) Bioenergetics of sulphate-reducing bacteria in relation to their environmental impact. Biodegradation 9, 201-212.

Hamilton W. A. and Lee W. (1995) Biocorrosion. In Sulfate reducing bacteria (ed. L. B. Larry). Plenum press.

Hansen H. C. B. (1989) Composition, stabilization, and light absorption of iron(II) iron(III) hydroxy-carbonate ('Green rust'). Clay Miner 24(4), 663-9.

Hansen H. C. B., Borggaard O. K., and Sørensen J. (1994) Evaluation of the free energy of formation of $\mathrm{Fe}(\mathrm{II})-\mathrm{Fe}(\mathrm{III})$ hydroxide-sulphate (green rust) and its reduction of nitrite. Geochim Cosmochim Acta 58, 2599-608.

Hansen H. C. B. and Inge F. P. (1999) Interaction of synthetic sulphate "green rust" with phosphate and the crystallization of vivianite. Clay Clay Miner 47(3), 312-18.

Herbert R. B., Benner S. G., Pratt A. R., and Blowes D. W. (1998) Surface chemistry and morphology of poorly crystalline iron sulfides precipitated in media containing sulfate-reducing bacteria. Chem Geol 144, 87-97.

Jeffrey R. and Melchers R. E. (2003) Bacteriological influence in the development of iron sulphide species in marine immersion environments. Corros Sci 45(4), 693-714.

Katrnachuk O. V., Kurochkina S. Y., and Tuovinen O. H. (2002) Growth of sulfate-reducing bacteria with solid-phase electron acceptor. Appl Microbiol Biotechnol 58, 482-486.

Konhauser K. O. (1997) Bacterial iron biomineralization in nature. FEMS Microbiol Rev 20, 315-326.

Kostka J. and Nealson K. H. (1995) Dissolution and reduction of magnetite by bacteria. Environ Sci Technol 29, 2535-40.

Kowalski W., Holub W., Wolicka D., Przytocka-Jusiak M., and Blaszczyk M. (2003) Sulphur balance in anaerobic cultures of microorganisms in medium with phosphogypsum and sodium lactate. Archiwum Mineralogiczne, 33-40.

Kukkadapu R. K., Zachara J. M., Fredrickson J. F., and Kennedy D. W. (2004) Biotransformation of two-line silica-ferrihydrite by a dissimilatory $\mathrm{Fe}$ (III)-reducing bacterium: formation of carbonate green rust in the presence of phosphate. Geochim Cosmochim Acta 68, 2799-2814. 
Lagarec K. and Rancourt D.G. (1997) Extended Voigt-based analytic lineshape method for determining $\mathrm{N}$-dimensional correlated hyperfine parameters distributions in Mössbauer spectroscopy.Nucl. Instr.and Meth.in Phys.Res. B 129, 266-280.

Lee A. K., Buehler M. G., and Newman D. K. (2006) Influence of dual-spices biofilm on the corrosion of mild steel. Corros Sci 48, 165-178.

Legrand L., Abdelmoula M., Géhin A., Chausse A., and Génin J.-M. R. (2001) Electrochemical formation of a new $\mathrm{Fe}(\mathrm{II})-\mathrm{Fe}(\mathrm{III})$ hydroxy-carbonate green rust: characterisation and morphology. Electrochimica Acta 46(12), 1815-1822.

Lovley D. R. (2000) Iron(III) and Mn(IV) reduction. In Environmental microbe-metal interactions (ed. D. R. Lovley). ASM Press.

Marchal R. (1999) Rôle des bacteries sulfurogènes dans la corrosion du fer. Oil and Gaz Sci. technol. 54, 649-659.

Mcintyre N. S. and Zetaruk D. G. (1977) X ray photoelectron spectroscopic studies of iron oxides. Anal Chem 49, 1521-1529.

Mullet M., Boursiquot S., Abdelmoula M., Génin J.-M., and Ehrhardt J. J. (2002) Surface chemistry and structural properties of mackinawite prepared by reaction of sulfide ions with metallic iron. Geochim Cosmochim Acta. 66, 829-836.

Myers C. R. and Nealson K. H. (1990a) Iron mineralization by bacteria: metabolic coupling of iron reduction to cell metabolism in Alteromonas putrefaciens MR-1. In Iron biominerals (ed. R. B. a. B. Frankel, R. P.), pp. 131-149. Plenum Press.

Myers C. R. and Nealson K. H. (1990b) Respiration-linked proton translocation coupled to anaerobic reduction of manganese(IV) and iron(III) in Shewanella putrefaciens MR-1. J Bacteriol 172(11), 6232-8.

Neal A. L., Techkarjanaruk S., Dohnalkova A., McCready D., Peyton B. M., and Geesey G. G. (2001) Iron sulfide ans dulfur species produced at hematite surfaces in the presence of sulfate-reducing bacteria. Geochim Cosmochim Acta 65, 223-235.

Nealson K. H. and Saffarini D. (1994) Iron and manganese in anaerobic respiration: environmental significance, physiology, and regulation. Annu Rev Microbiol 48, 31143.

Nesbitt H. W. and Muir I. J. (1994) X-ray photoelectron spectroscopic study of a pristine pyrite surface reacted with water vapor and air. Geochim Cosmochim Acta 58, 46674679.

Olowe A. A., Bauer P., Génin J.-M. R., and Guezennec J. (1989) Mössbauer effect evidence of the existence of green rust II transient compounds from bacterial corrosion in marine sediments. Corros NACE 45, 229-35.

Olowe A. A., Génin J.-M. R., and Guezennec J. (1990) Mössbauer effect study of microbially induced corrosion of steel by sulphate reducing bacteria in marine sediments: role of green rust 2. In Microbially influenced corrosion and deterioration (ed. N. J. Dowling, M. W. Mitleman, and J. C. Danko), pp. 65-72. University of Tennessee and NACE.

Ona-Nguema G., Abdelmoula M., Jorand F., Benali O., Géhin A., Block J.-C., and Génin J.M. R. (2002) Iron (II,III) hydroxycarbonate green rust formation and stabilization from lepidocrocite bioreduction. Environ Sci Technol 36(1), 16-20.

Ona-Nguema G., Carteret C., Benali O., Abdelmoula M., Génin J.-M. R., and Jorand F. (2004) Competitive formation of hydroxycarbonate green rust I vs hydroxysulphate green rust II in Shewanella putrefaciens cultures. Geomicrobiol J 21(3), 79-90.

Parmar N., Gorby Y. A., Beveridge T. J., and Ferris F. G. (2001) Formation of green rust and immobilization of nickel in response to bacterial reduction of hydrous ferric oxide. Geomicrobiol J 18(4), 375-385.

Peiffer S., Dos Santos M., Wehrll B., and Gächter R. (1992) Kinetics and mechanism of the reaction of $\mathrm{H}_{2} \mathrm{~S}$ with lepidocrocite. Environ Sci Tech 26, 2408-2413. 
Peulon S., Legrand L., Antony H., and Chaussé A. (2003) Electrochemical deposition of thin films of green rusts 1 and 2 on inert gold substrate. Electrochemistry communication 5, 208-213.

Popa R. and Kinkle B. K. (2000) Discrimination among iron sulfide species formed in microbial cultures. J Microbiol Meth. 42, 167-174.

Poulton S. W. (2003) Sulfide oxidation and iron dissolution kinetics during the reaction of dissolved sulfide with ferrihydrite. Chem Geol 202, 79-94.

Poulton S. W., Krom M. D., Van Rijn J., and Raiswell R. (2002) The use of hydrous iron (III) oxides for the removal of hydrogen sulphide in aqueous system. Water Res. 36, 825834.

Pratt A. R., Nesbitt H. W., and Muir I. J. (1994) Generation of acids from mine waste: oxidative leaching of pyrrhotite in dilute $\mathrm{H}_{2} \mathrm{SO}_{4}$ solutions at $\mathrm{pH}$ 3.0. Geochim Cosmochim Acta. 58, 5147-5159.

Refait P., Charton A., and Génin J.-M. R. (1998) Identification, composition, thermodynamic and structural properties of a pyroaurite-like iron(II)-iron(III) hydroxy-oxalate Green Rust. Eur J Sol State Inor 35(10-11), 655-66.

Refait P., Gehin A., Abdelmoula M., and Genin J.-M. R. (2003a) Coprecipitation thermodynamics of iron(II-III) hydroxysulphate green rust from $\mathrm{Fe}$ (II) and $\mathrm{Fe}$ (III) salts. Corros Sci 45(4), 659-676.

Refait P., Memet J.-B., Bon C., Sabot R., and Génin J.-M. R. (2003b) Formation of the Fe(II)$\mathrm{Fe}(\mathrm{III})$ hydroxysulphate green rust during marine corrosion of steel. Corros Sci 45, 833-845.

Refait P., Simon L., and Génin J.-M. R. (2000) Reduction of $\mathrm{SeO}_{4}{ }^{2-}$ anions and anoxic formation of iron(II)-iron(III) hydroxy selenate green rust. Environ Sci Technol 34(5), 819-25.

Roden E. E. and Zachara J. M. (1996) Microbial reduction of crystalline iron (III) oxides: influence of oxide surface area and potential for cell growth. Environ Sci Technol 30, 1618-28.

Schaufuss A. G., Nesbitt H. W., Karito I., Laajalehto K., Bancroft G. M., and Szargan R. (1998) Incipient oxidation of fractured pyrite surfaces in air. J. Electron Spectros and Related Phenom 96, 69-82.

Simon L., Francois M., Refait P., Renaudin G., Lelaurain M., and Génin J.-M. R. (2003) Structure of the Fe(II-III) layered double hydroxysulphate green rust two from Rietveld analysis. Solid State Sci 5, 327-334.

Simon L., Génin J.-M. R., and Refait P. (1997) Standard free enthalpy of formation of Fe(II)$\mathrm{Fe}(\mathrm{III})$ hydroxysulphite green rust one and its oxidation into hydroxysulphate green rust two. Corros Sci 39(9), 1673-85.

Stampfl P. P. (1969) Basic Fe(II)(III)-carbonate in rust. Corros Sci 9, 185-7.

Thomas J. E., Jones C. F., Skinner W. M., and Smart R. C. (1998) The role of surface species in the inhibition of pyrrhotite dissolution in acid conditions. Geochim Cosmochim Acta 9, 1555-1565.

Trolard F., Génin J.-M. R., Abdelmoula M., Bourrié G., Humbert B., and Herbillon A. (1997) Identification of a green rust mineral in a reductomorphic soil by Mössbauer and Raman spectroscopy. Geochim Cosmochim Acta 61, 1107-11.

Yao W. and Millero F. J. (1996) Oxidation of hydrogen sulfide by hydrous Fe(III) oxides seawater. Marine Chemistry 52, 1-16.

Yi-Lang L., Hojatollah V., Sears S. K., Yang J., Deng B., and Zangh C. L. (2004) Iron reduction and alteration of nontronite NAu-2 by sulfate-reducing bacteria. Geochim Cosmochim Acta 68, 3251-3260. 
Zachara J. M., Kukkadapu R. K., Fredrickson J. K., Gorby Y. A., and Smith S. C. (2002) Biomineralization of poorly crystalline $\mathrm{Fe}$ (III) oxides by dissimilatory metal reducing bacteria (DMRB). Geomicrobiol J 19(2), 179-207.

Zachara J. M., Li S.-M., Kennedy D. W., Smith S. C., and Gassman P. L. (1998) Bacterial reduction of crystalline $\mathrm{Fe}^{3+}$ oxides in single phase suspensions and subsurface materials. Amer Mineral 83, 1426-43.

Zegeye A., Ona-Nguema G., Carteret C., Huguet L., Abdelmoula M., and Jorand F. (2005) Formation of hydroxysulphate green rust 2 as a single iron(II-III) mineral in microbial culture. Geomicrobiol. J. 22, 389-399.

Zinkevich V., Bogdarina I., Kang H., Hill M. A. W., Tapper R., and Beech I. B. (1996) Characterization of exopolymers produced by different isolates of marine sulphatereducing bacteria. Int Biodete Biodegr 37, 163-173. 
Table 1

\begin{tabular}{|c|c|c|c|c|c|}
\hline $\begin{array}{l}\text { Incubation time } \\
\text { and temperature }\end{array}$ & $\delta^{\mathrm{a}}(\mathrm{m}$ & $\left.\mathrm{m} \mathrm{s}^{-1}\right)$ & $\begin{array}{l}\Delta \text { or } 2 \varepsilon^{b} \\
\left(\mathrm{~mm} \mathrm{~s}^{-1}\right)\end{array}$ & $\mathrm{H}^{\mathrm{c}}(\mathrm{kOe})$ & $\begin{array}{c}\text { Relative } \\
\text { abundance (\%) }\end{array}$ \\
\hline \multirow{3}{*}{$\begin{array}{l}\mathrm{t}=0 \\
77 \mathrm{~K}\end{array}$} & GR & $\mathrm{D}_{1}: 1.27$ & 2.92 & & 36 \\
\hline & & $\mathrm{D}_{2}: 0.48$ & 0.44 & & 21 \\
\hline & Lepido & $\mathrm{D}_{\mathrm{L}}: 0.47$ & 0.62 & & 43 \\
\hline \multirow{7}{*}{$\begin{array}{l}t=3 \text { days } \\
100 \mathrm{~K}\end{array}$} & GR & $\mathrm{D}_{1}: 1.24$ & 2.87 & & 16 \\
\hline & & $\mathrm{D}_{2}: 0.53$ & 0.39 & & 10 \\
\hline & Lepido & $\mathrm{D}_{\mathrm{L}}: 0.46$ & 0.73 & & 46 \\
\hline & Vivianite & $: 1.33$ & 3.2 & & 7 \\
\hline & & $: 1.24$ & 2.54 & & 6 \\
\hline & Greigite & $: 0.47$ & -0.14 & 475 & 9 \\
\hline & & $: 0.84$ & 0.02 & 277 & 6 \\
\hline \multirow{6}{*}{$\begin{array}{l}\mathrm{t}=20 \text { days } \\
215 \mathrm{~K}\end{array}$} & GR & $\mathrm{D}_{1}: 1.18$ & 2.6 & & 34 \\
\hline & & $\mathrm{D}_{2}: 0.4$ & 0.5 & & 32 \\
\hline & Lepido & $\mathrm{D}_{\mathrm{L}}: 0.47$ & 0.5 & & 5 \\
\hline & Vivianite & $: 1.20$ & 2.96 & & 13 \\
\hline & Greigite & $: 0.41$ & -0.09 & 419 & 11 \\
\hline & & $: 0.85$ & -0.5 & 387 & 4 \\
\hline \multirow{6}{*}{$\begin{array}{l}t=300 \text { days } \\
13 \mathrm{~K}\end{array}$} & GR & $\mathrm{D}_{1}: 1.24$ & 2.67 & & 29 \\
\hline & & $\mathrm{D}_{2}: 0.45$ & 0.43 & & 17 \\
\hline & Vivianite & $: 1.27$ & 3.1 & & 14 \\
\hline & Greigite & $: 0.49$ & 0 & 280 & 20 \\
\hline & & $: 0.88$ & -0.5 & 355 & 8 \\
\hline & Iron oxide & $: 0.48$ & -0.15 & 504 & 12 \\
\hline
\end{tabular}
(a) Isomer shift relative to metallic iron
(b) Quadrupole splitting or quadrupole shift
(c) Hyperfine magnetic field 
Table 2

\begin{tabular}{|c|c|c|}
\hline Species & Binding energy $(\mathrm{eV})$ & References \\
\hline \multicolumn{3}{|l|}{$\operatorname{Fe}\left(2 p_{3 / 2}\right)$} \\
\hline \multirow[t]{2}{*}{$\mathrm{Fe}(\mathrm{II})-\mathrm{S}$} & 706.8 & (Mullet et al., 2002) \\
\hline & 707.3 & (Herbert et al., 1998) \\
\hline \multirow[t]{2}{*}{$\mathrm{Fe}(\mathrm{II})-\mathrm{O}$} & 709.5 & (Mcintyre and Zetaruk, 1977) \\
\hline & 709.0 & (Thomas et al., 1998) \\
\hline \multirow[t]{2}{*}{$\mathrm{Fe}(\mathrm{III})-\mathrm{S}$} & $709.20 *$ & (Pratt et al., 1994) \\
\hline & $709.15^{*}$ & (Herbert et al., 1998) \\
\hline \multirow[t]{2}{*}{$\mathrm{Fe}(\mathrm{III})-\mathrm{O}$} & $710.30 *$ & (Nesbitt and Muir, 1994) \\
\hline & $710.8^{*}$ & (Schaufuss et al., 1998) \\
\hline \multicolumn{3}{|l|}{$\mathbf{S}\left(2 \mathbf{p}_{3 / 2}\right)$} \\
\hline \multirow[t]{2}{*}{$S^{2-}$} & 161.3 & (Mullet et al., 2002) \\
\hline & 160.9 & (Herbert et al., 1998) \\
\hline $\mathrm{S}_{2}{ }^{2-}$ & 162.2 & (Herbert et al., 1998) \\
\hline \multirow[t]{2}{*}{$\mathrm{S}_{\mathrm{n}}^{2-}$} & 163.6 & (Nesbitt and Muir, 1994) \\
\hline & 163.4 & (Thomas et al., 1998) \\
\hline $\mathrm{SO}_{4}^{2-}$ & 168.1 & (Thomas et al., 1998) \\
\hline
\end{tabular}

*Measurements corresponding to the main component of the multiplet peaks 
Table 3

\begin{tabular}{|c|c|c|c|}
\hline $\mathrm{BE}(\mathrm{eV})$ & FHWM & Area & Species \\
\hline \multicolumn{4}{|c|}{ Starting material GR2 $\left(\mathrm{SO}_{4}{ }^{2-}\right)$} \\
\hline 168.2 & 1.1 & 100 & sulfate \\
\hline \multicolumn{4}{|c|}{$T=300$ days } \\
\hline 160.9 & 0.9 & 66.0 & monosulfide \\
\hline 161.8 & 1.2 & 20.1 & disulfide \\
\hline 163.3 & 1.4 & 13.9 & polysulfide \\
\hline
\end{tabular}




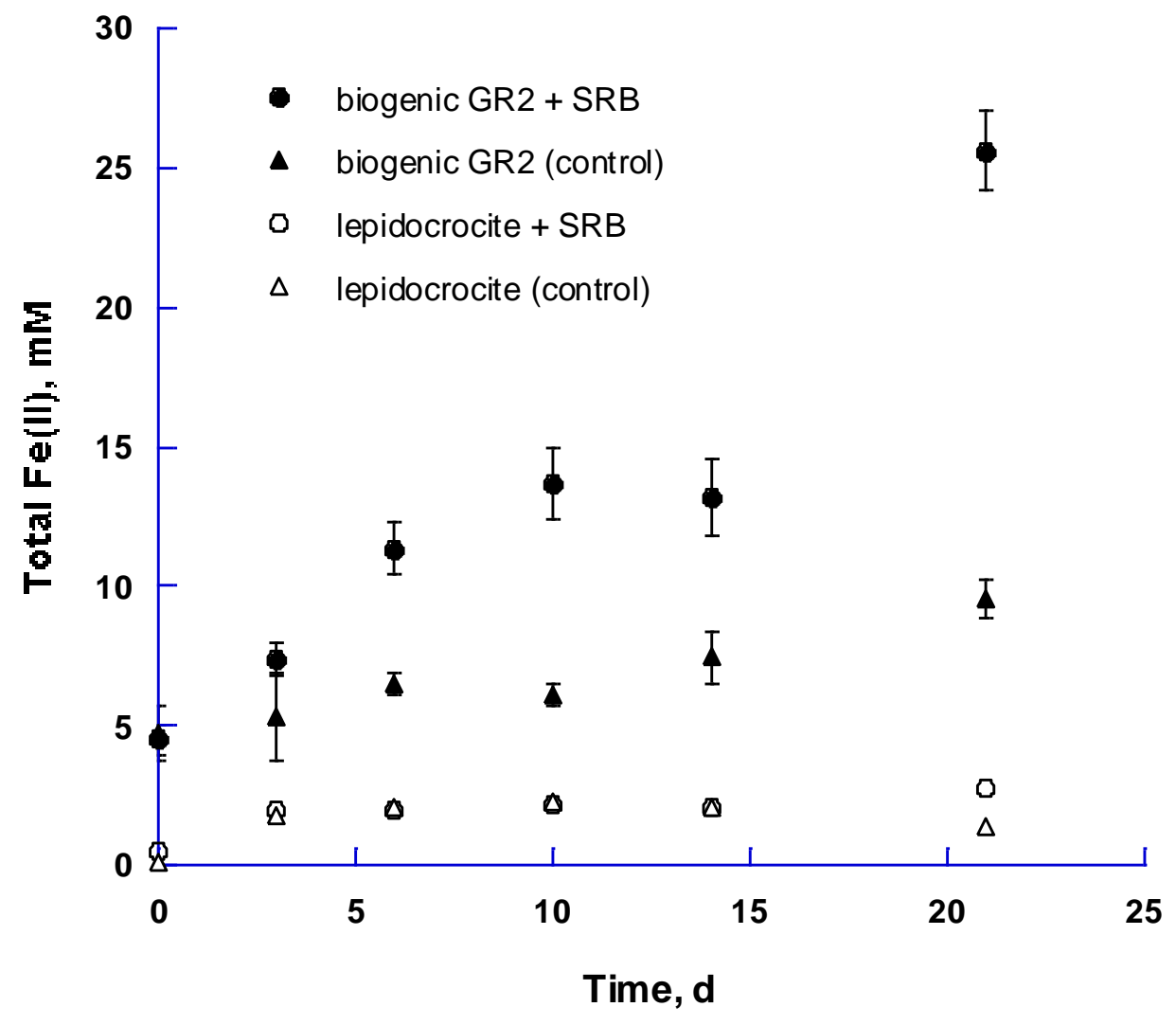

Figure 1 


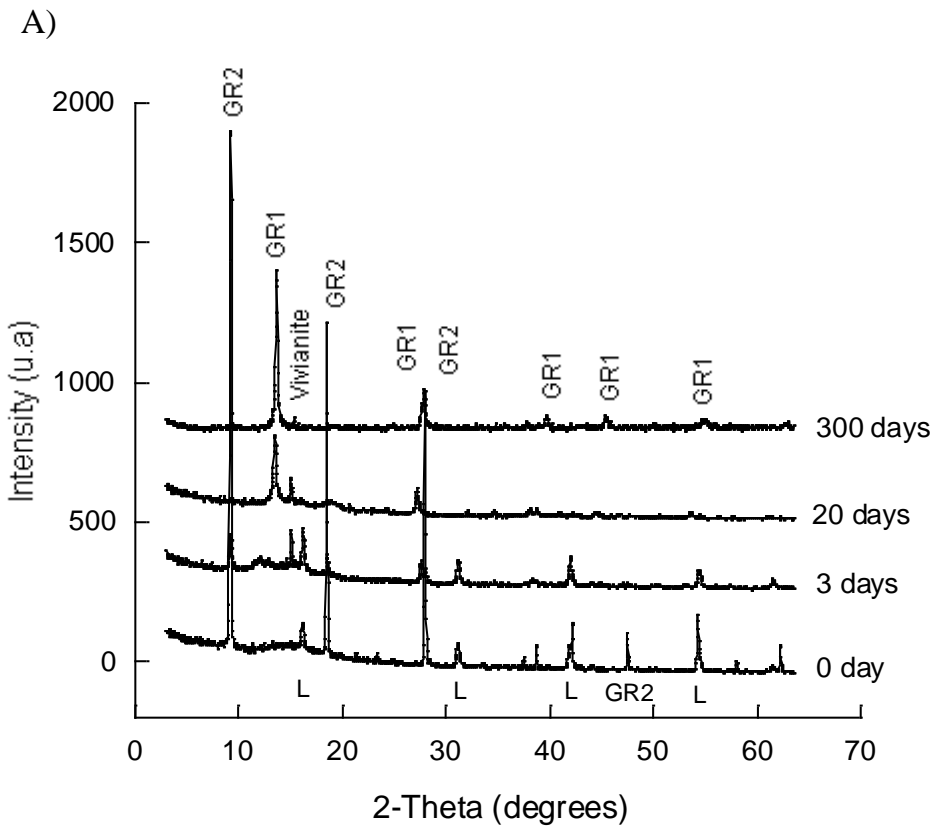

B)

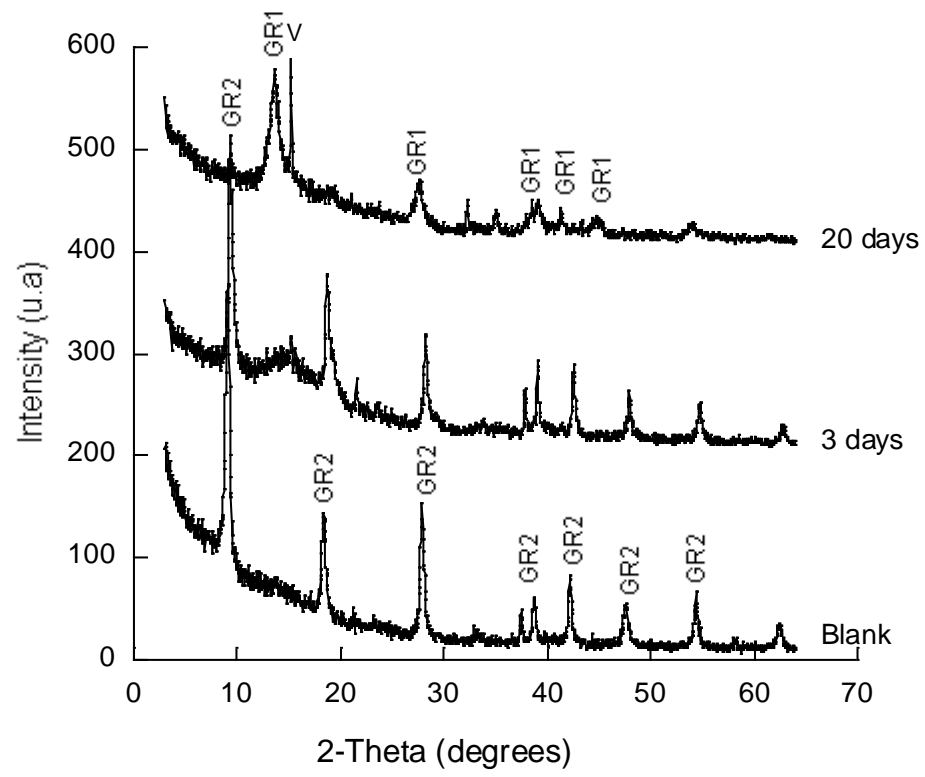

Figure 2 

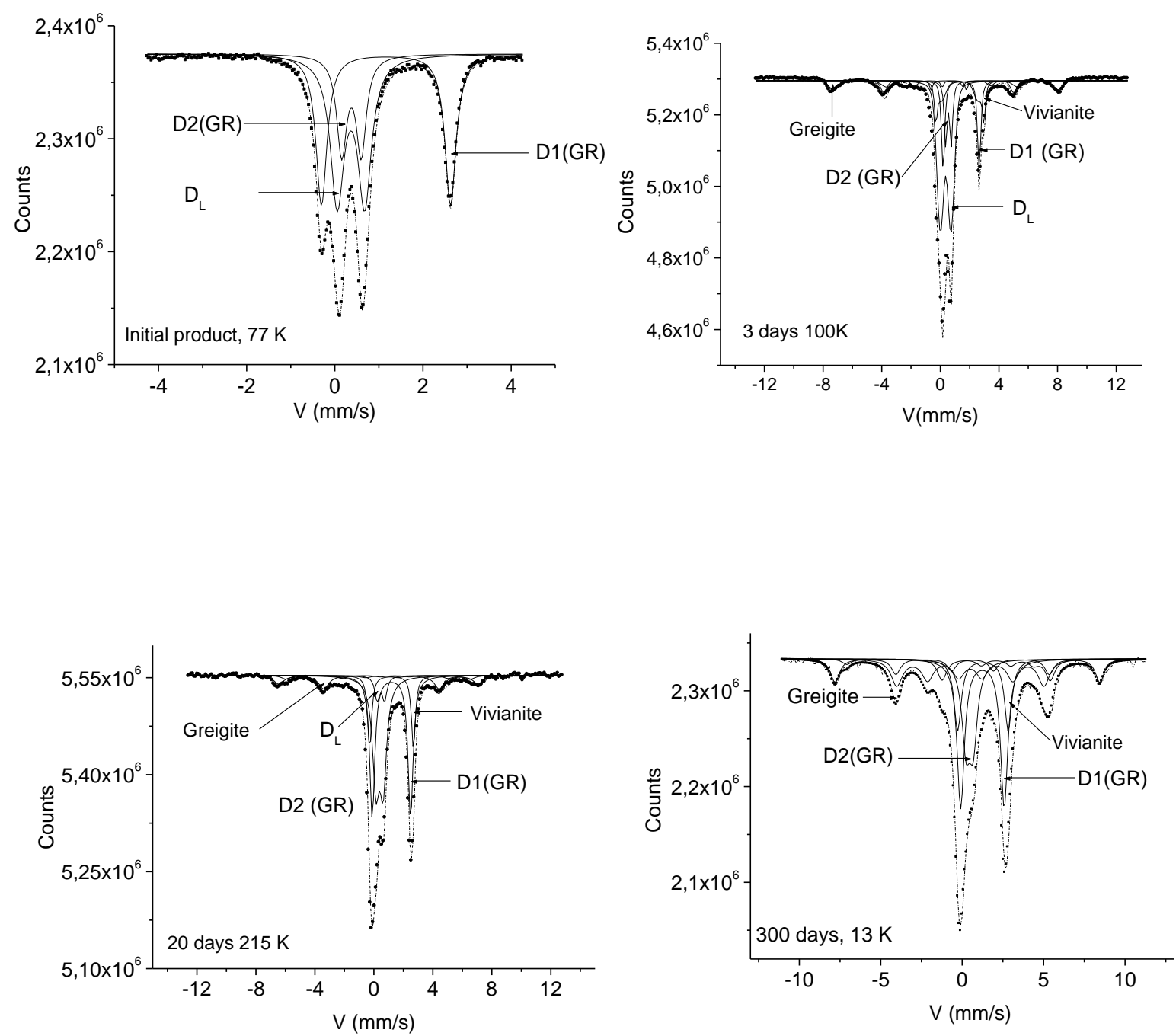

Figure 3 
A)

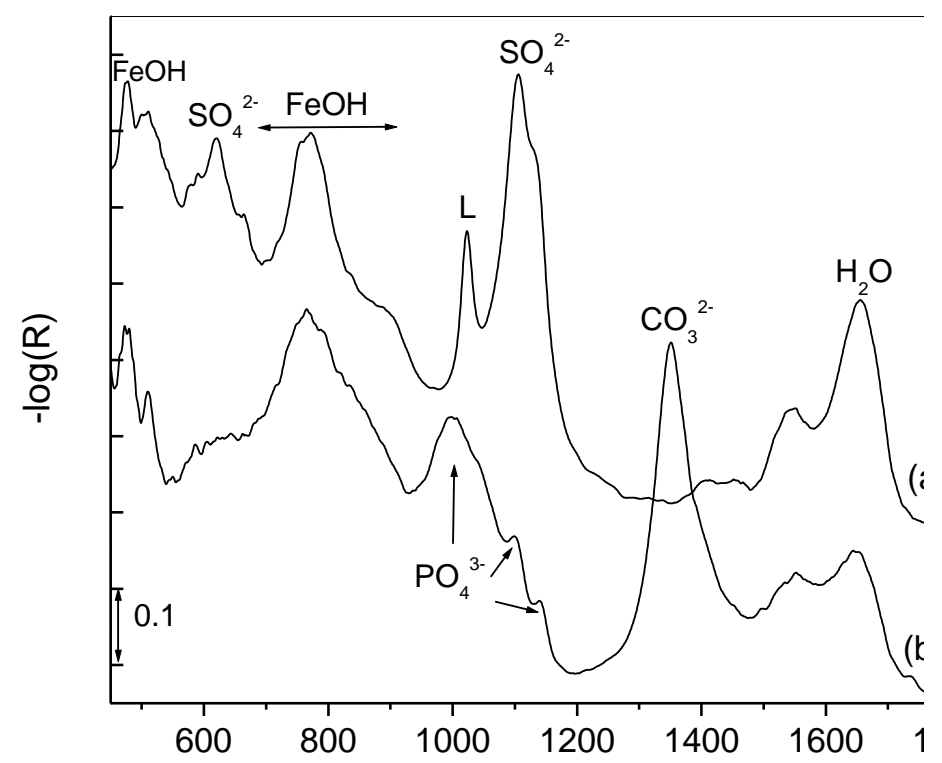

B)

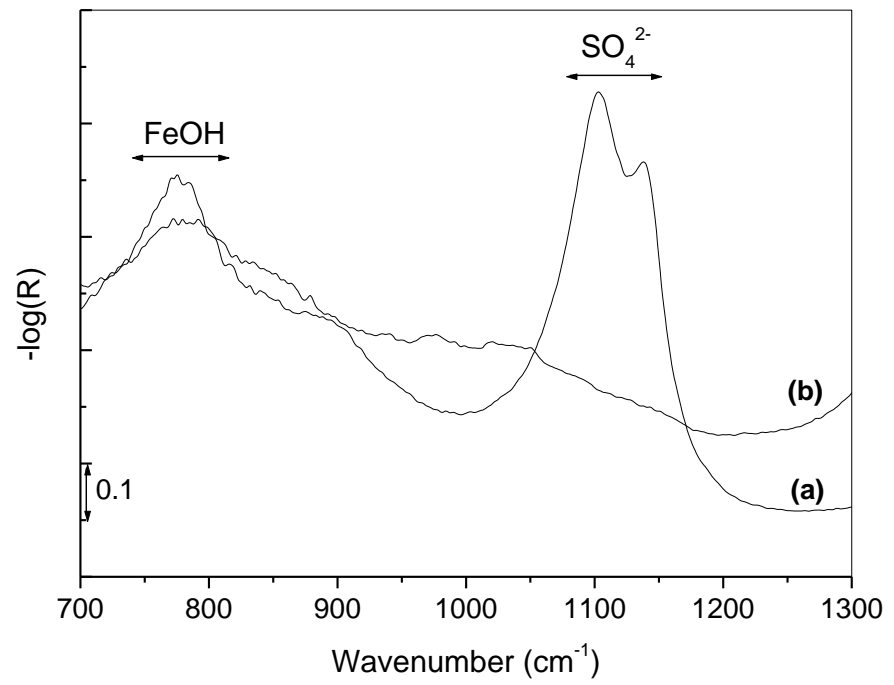

Figure 4 


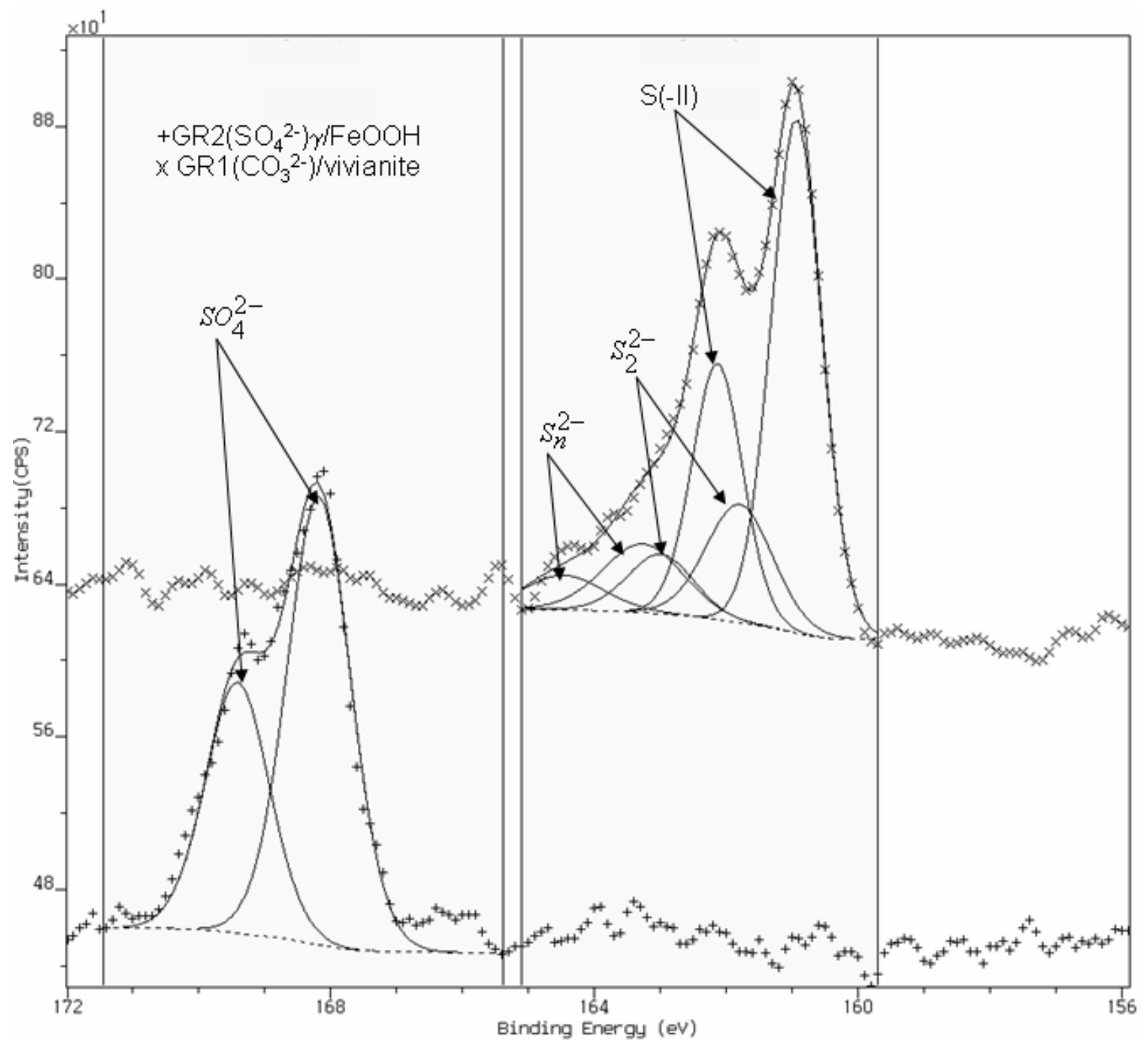

Figure 5 


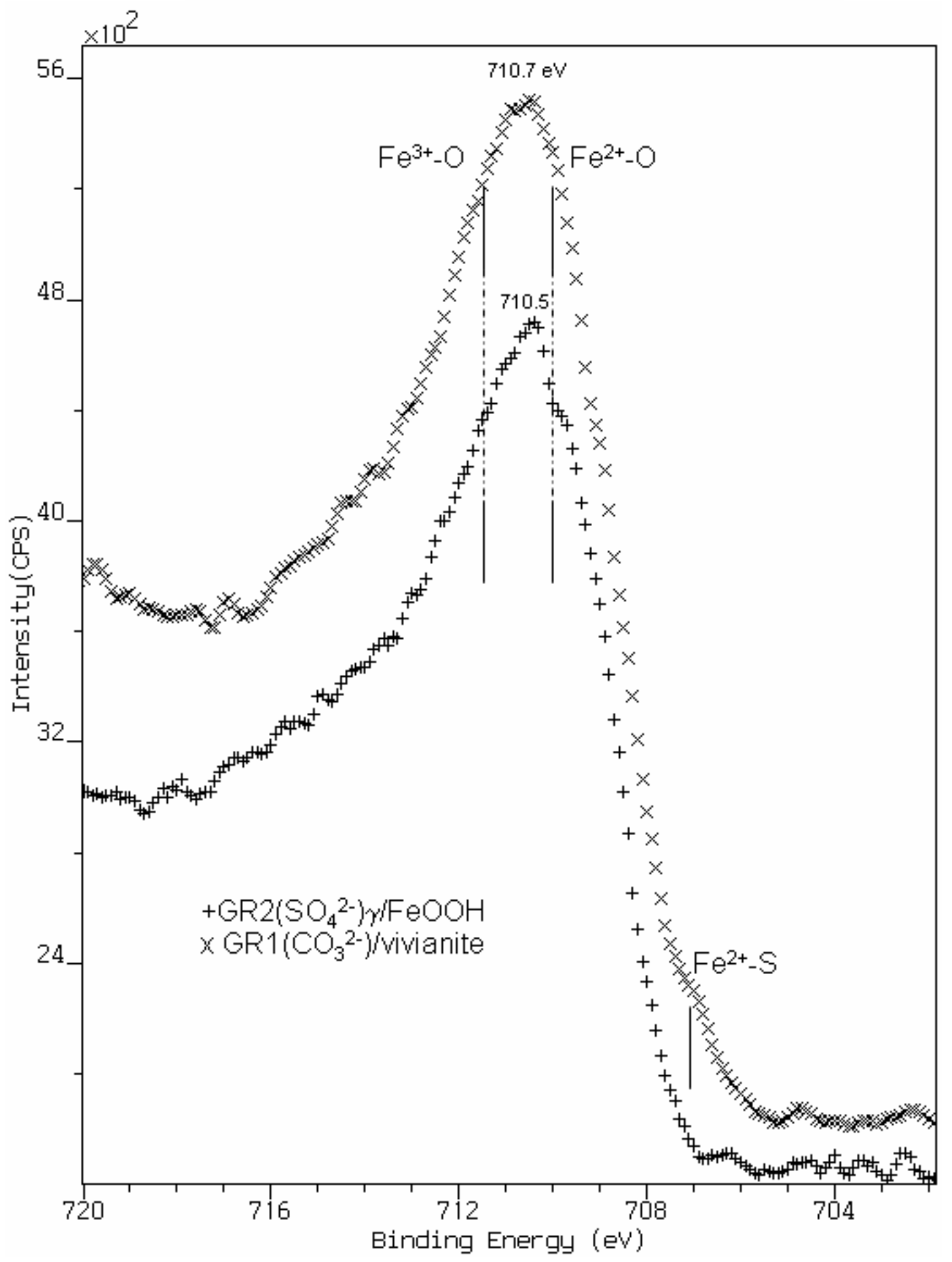

Figure 6 

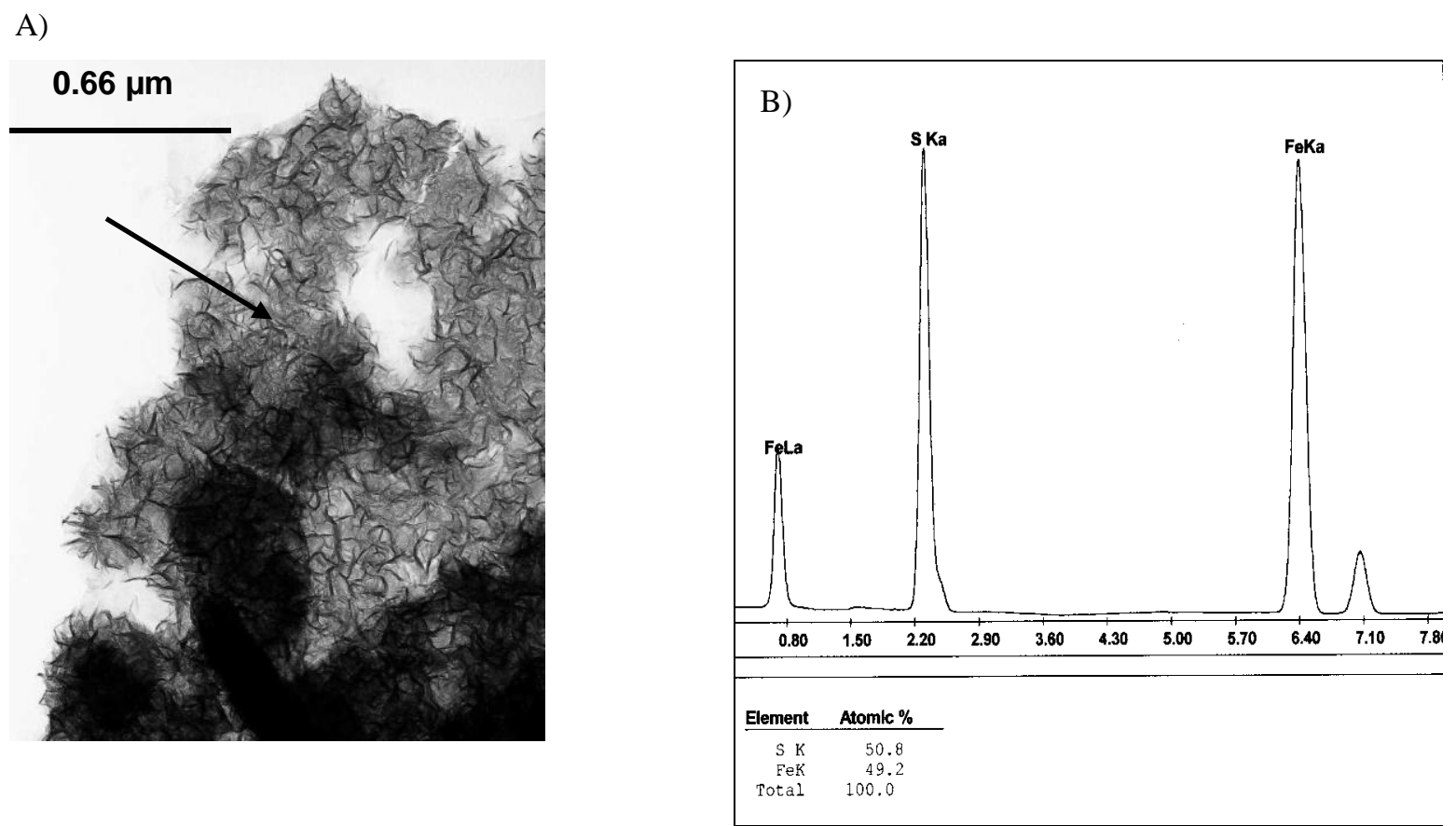

Figure 7 
Bulk solution

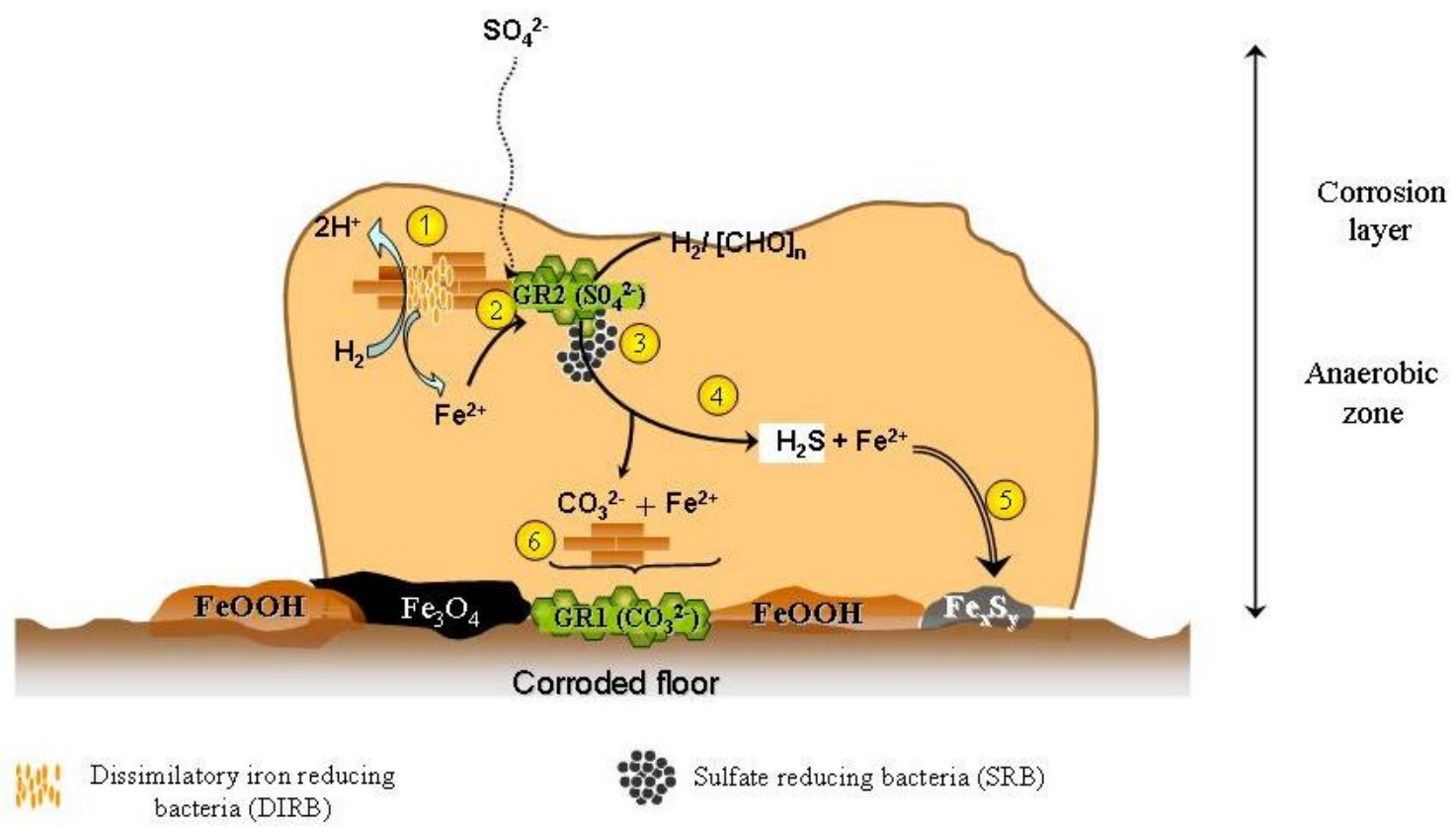

Figure 8 


\section{Figure captions}

Figure 1 Monitoring of the total ferrous ion (in the solid and aqueous phase) production during the incubation of the mixture of $\mathrm{GR} 2\left(\mathrm{SO}_{4}{ }^{2-}\right)$ and lepidocrocite with $D$. alaskensis during the 21 days of incubation. Error bars show \pm standard deviation of $n=4$ cultures.

Figure 2 XRD spectra of the mineral solids from the treatments with $D$. alaskensis on biotic GR2 $\left(\mathrm{SO}_{4}{ }^{2-}\right)$ plus lepidocrocite (Fig. 2A) and abiotic GR2 $\left(\mathrm{SO}_{4}{ }^{2-}\right)$ (Fig. 2B) after different incubation time (day 0, day 3, day 20 and day 300). Green rust 2, lepidocrocite, green rust 1 and vivianite peaks are indicated by GR2, L, GR1, V respectively.

Figure 3 TMS spectra of solid phase obtained at different times of incubation (day 0, day 3, day 20 and day 300).

Figure 4 Infrared spectra of the mineral solid from the from the treatments with $D$. alaskensis on biotic GR2 $\left(\mathrm{SO}_{4}{ }^{2-}\right)$ plus lepidocrocite and abiotic GR2( $\left.\mathrm{SO}_{4}{ }^{2-}\right)$. Fig. $4 \mathrm{~A}$ gives spectra for (a) $\mathrm{GR} 2\left(\mathrm{SO}_{4}{ }^{2-}\right) / \gamma-\mathrm{FeOOH}$ minerals and (b) 300 days after SRB inoculation. Fig. 4B displays spectrum of (a) abiotic GR2 $\left(\mathrm{SO}_{4}{ }^{2-}\right)$ and (b) 20 days after SRB inoculation focused on the spectral range of sulfate adsorption (1300-700 $\left.\mathrm{cm}^{-1}\right)$. (L: lepidocrocite). Before analysis each mineral was kept in an anaerobic chamber for $24 \mathrm{~h}$ under $90 \%$ relative humidity.

Figure 5 XPS $\mathrm{Fe}\left(2 \mathrm{p}_{3 / 2}\right)$ spectra of (a) GR2 $\left(\mathrm{SO}_{4}{ }^{2-}\right) / \gamma$-FeOOH minerals and (b) 300 days after SRB inoculation. 
Figure 6 XPS S(2p) spectra of (a) GR2 $\left(\mathrm{SO}_{4}{ }^{2-}\right) / \gamma$-FeOOH minerals and (b) 300 days after SRB inoculation. The vertical lines (from left to right) indicate the biding energies of $\mathrm{Fe}^{3+}-\mathrm{O}, \mathrm{Fe}^{2+}-$ $\mathrm{O}$ and $\mathrm{Fe}^{2+}-\mathrm{S}$ respectively.

Figure 7 (A) TEM image of solids formed after 20 days of incubation. The arrow indicates FeS compound, whose composition is determinate by the SAED analysis (B).

Figure 8 A model of DIRB and SRB interaction via $\mathrm{GR} 2\left(\mathrm{SO}_{4}{ }^{2-}\right)$ formation during a corrosion process of an iron surface in sea water. Representative SRB cells inside a tubercle of corrosion are shown. The hypothetical reactions occurring during DIRB and SRB interactions are numbered (path $1 \rightarrow 6$ ) and are issued from the following references. Reaction $\mathrm{n}^{\circ} 1$, (Zegeye et al., 2005, reaction $\mathrm{n}^{\circ} 2$, (Géhin et al., 2002), reaction $\mathrm{n}^{\circ} 3,4$, 5, (this study) and reaction $n^{\circ} 6$, (Drissi et al., 1995). Details are provided in the text. 


\section{Table captions}

Table 1 Mössbauer parameters of solid phase obtained at different times of incubation (day 0, day 3, day 20 and day 300).

Table 2 Binding energies for $\mathrm{S}\left(2 \mathrm{p}_{3 / 2}\right)$ and $\mathrm{Fe}\left(2 \mathrm{p}_{3 / 2}\right)$ peaks in various model compounds.

Table 3 XPS peak fit parameters: peak energy, FWHM and area ratio of the $S(2 p)$ spectra. Binding energy peak location is accurate to $0.1 \mathrm{eV}$. Area for $S(2 \mathrm{p})$ includes $2 \mathrm{p}_{1 / 2}$ and $2 \mathrm{p}_{3 / 2}$ contributions. 